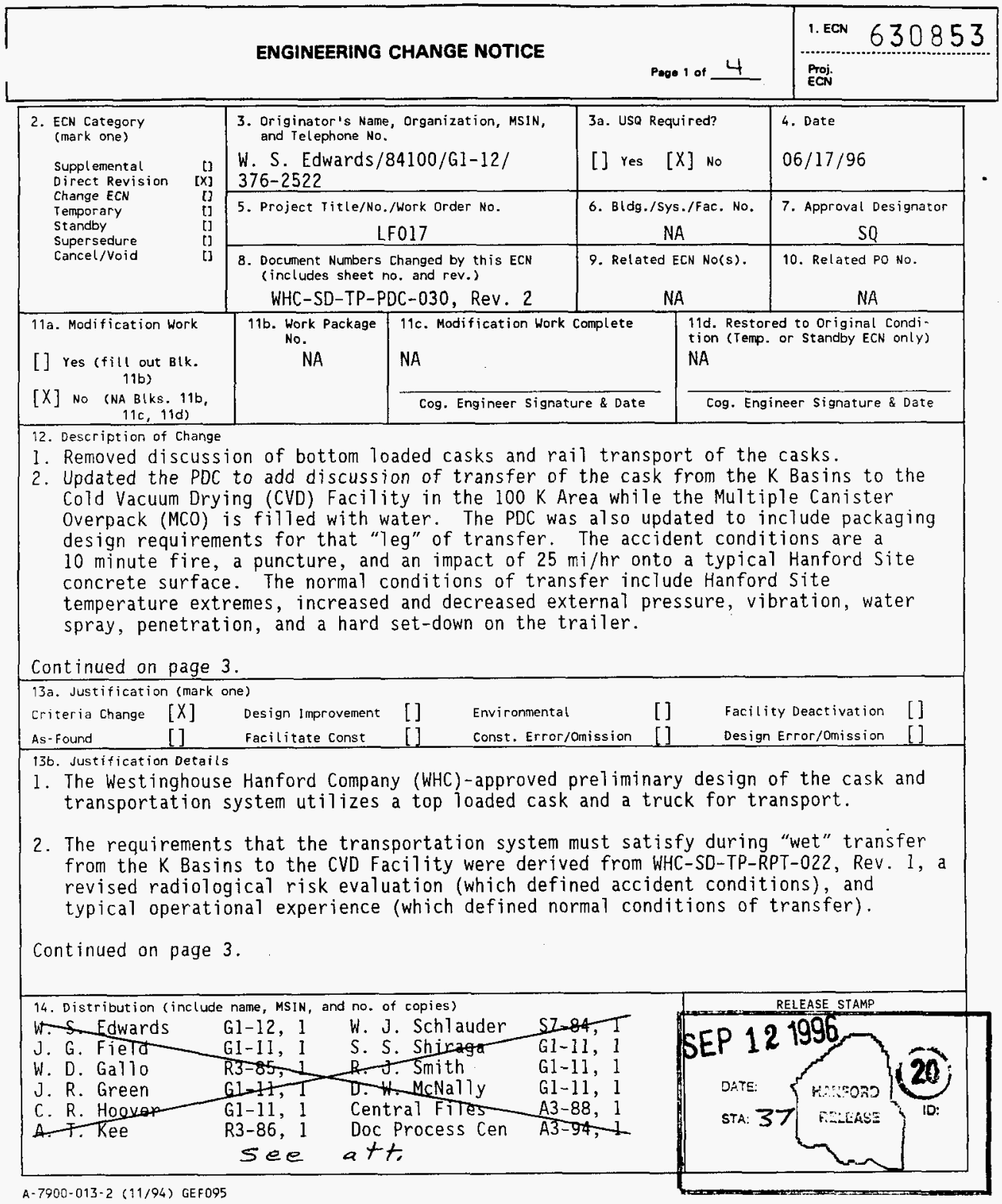




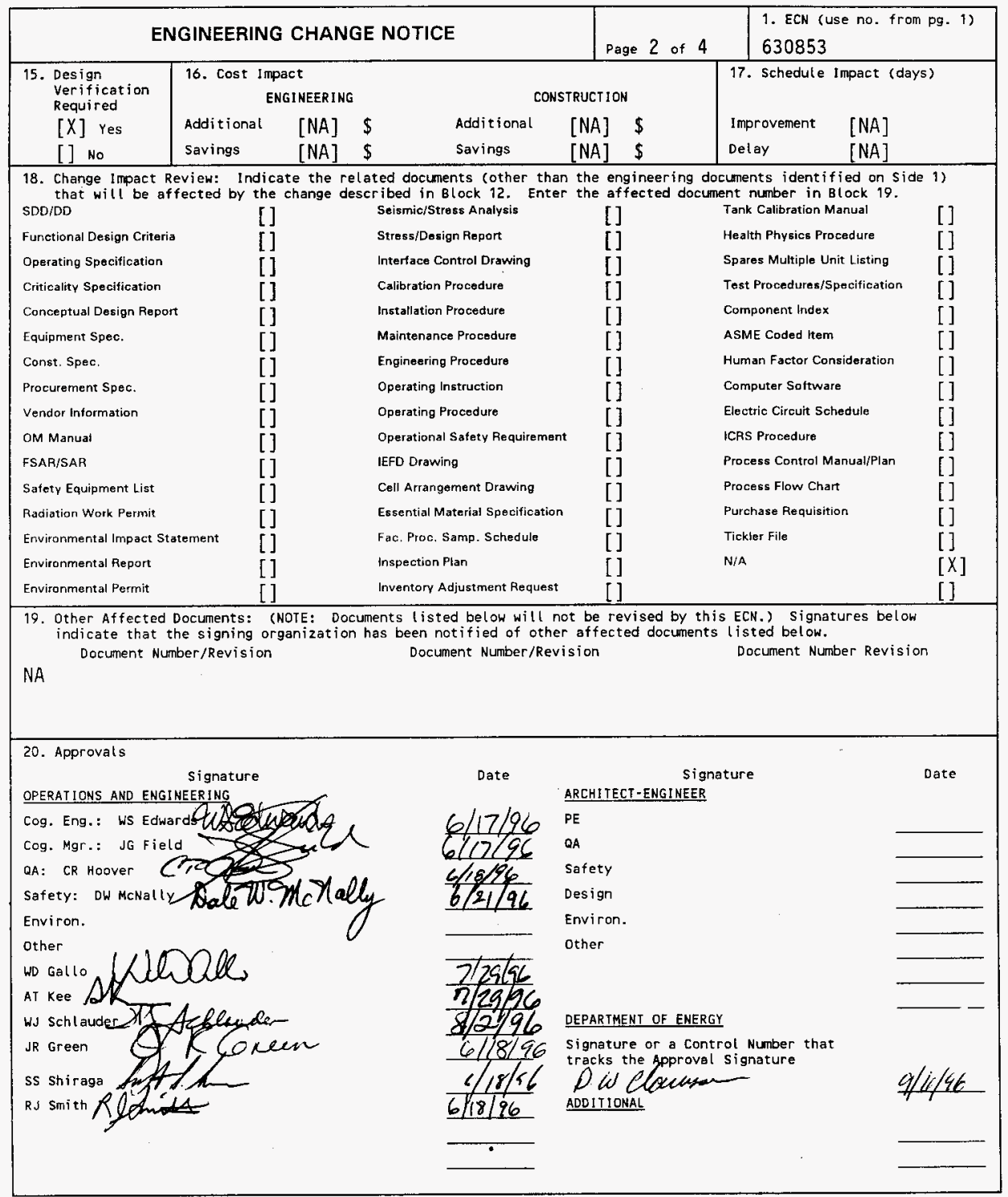


12. Description of Change (Continued)

3. Updated source term based on a more current model.

4. Revised gas generation description to include discussion of gas generation methods: uranium corrosion, radiolysis, and fission gas release. Added requirement for backfilling MCO and cask cavity with inert gas to prevent flammable gas concentrations from accumulating.

5. Updated criticality section to assign a preliminary criticality transport index of 100 , to require that only one package, instead of two, must remain subcritical after the normal conditions of transport, and to require that three packages in any stacking arrangement and closely reflected must remain subcritical.

6. Revised external cask contamination limits to require compliance with U.S. Department of Transportation (DOT) limits.

7. Added description of operations in the CVD Facility.

8. Added requirement that the packaging be designed to meet the Hanford Site Master Safety Rules and Occupational Safety and Health Administration (OSHA) regulations.

9. Added requirement that the cask be leakage rate testable.

10. Changed reference that provides guidance on designing maintenance features in accordance with as low as reasonably achievabie (ALARA).

11. Clarified post-accident containment requirements.

13b. Justification Details (Continued)

3. The source term was updated based on ECN 191402 to WHC-S-0396, Revision 1, Specification for Spent Nuclear Fuel (SNF) Path Forward Cask and Transportation System.

4. Discussion of gas generation methods was added to show how each method can be controlled. Inert gas must be added to the MCO cavity to prevent a flammable gas concentration from accumulating, since, with the uncertainty in gas generation rates and temperatures within the $\mathrm{MCO}$, it may not be possible to prevent hydrogen gas concentrations from exceeding $5 \%$. Backfilling with inert gas will remove oxygen from the $\mathrm{MCO}$, which is required to obtain a flammable gas mixture. Backfilling the cask cavity with inert gas provides an additional barrier between the oxygen and the possible high hydrogen concentration within the MCO.

5. These changes to the criticality requirements reflect the April 1, 1996, revision to the U.S. Nuclear Regulatory Commission (NRC) regulations to align those regulations with International Atomic Energy Agency (IAEA) regulations.

6. HSRCM-1, Hanford Site Radiological Control.Manual, does not address onsite shipments in contractor conveyances (U.S. Department of Energy [DOE] conveyance is defined as a vehicle owned by DOE and driven by DOE employees, not contractors). Since the DOT permits offsite shipments with the contamination levels listed in their regulations, the DOT limits are reasonable for the MCO cask. 
7. Since several operations that affect the payload will occur at the CVD Facility, descriptions of those operations were added to the POC.

8. All packaging systems used on the Hanford Site must comply with the Master Safety Rules and OSHA regulations.

9. Since the cask must be leak tested to show that it has been properly sealed, the cask must have provisions to allow leakage rate testing.

10. Guidance on designing maintenance features in accordance with ALARA principals is provided in WHC-SD-GN-3011, Radiological Design Guide, not HSRCM-1.

11. Based an WHC-SD-TP-RPT-022, Rev. 1, the cask seals may fail during the 30 minute fire that occurs during "dry" transfer of the fuel from the CVD Facility to the Canister storage Building (CSB), as long as the MCO is retained within the cask. This revision clarifies that point.

Design Verification of this change was performed and the changes were found not to adversely impact the underlying safety bases and parameters of the package. Nuclear verification was performed by J. R. Green. Structural/mechanical verification was performed by 5 . S. Shiraga. 


\title{
Packaging Design Criteria for the MCO Cask
}

\author{
W. S. Edwards
}

West inghouse Hanford Company, Rich land, WA 99352

U.S. Department of Energy Contract DE-ACO6-87RL10930

$\begin{array}{lll}\text { EDT/ECN: } & 630853 & \text { UC: } 513 \\ \text { Org Code: } 84100 & \text { Charge Code: LF037 } \\ \text { B\&R Code: } & 35 E W 31354 & \text { Total Pages: } 59\end{array}$

Key Words: Multiple Canister Overpack (MCO), Cask, Fuel Elements, $K$ Basins, Canister Storage Building (CSB), Packaging, Package, Cask

Abstract: Approximately 2,100 metric tons of unprocessed, irradiated nuclear fuel elements are presently stored in the $\mathrm{K}$ Basins. To permit cleanup of the $K$ Basins and fuel conditioning, the fuel will be transported from the K Basins to a Canister Storage Building in the 200 East Area. The purpose of this packaging design critería is to provide criteria for the design, fabrication, and use of a packaging system to transport the large quantities of irradiated nuclear fuel elements positioned within Multiple Canister Overpacks.

TRADEMARK DISCLAIMER. Reference herein to eny specific coumercial product, process, or service by trade name, trademark, manufacturer, or otherwise, does not necessarily constitute or imply its ondorsement, recombendation, or fovoring by the United stutes Government or any agency thereof or ite contrectors or aubcentractors.

Printed in the United States of Amorica. To obtain copies of this document, contact: UHC/BCS Document Control Services, P.0. Box 1970, Mailatop 16-08, Richlond HA 99352. Phone (509) 372-2420: Fax (509) 376-4989.
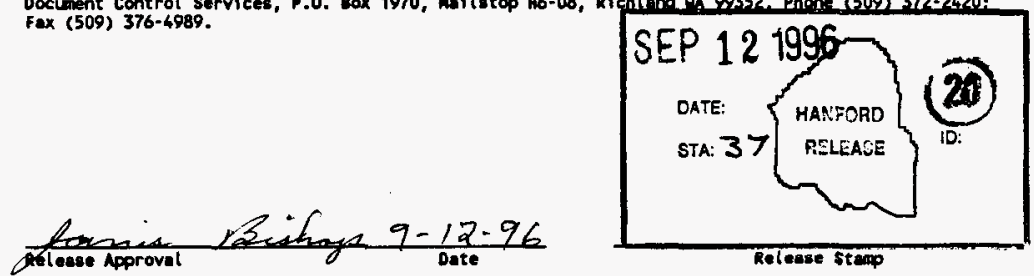

Release Stamp 


\begin{tabular}{|c|c|c|c|c|}
\hline & RECORD OF REVISION & $\begin{array}{l}\text { (1) Document Hum } \\
\text { WHC-SD-TP-PD }\end{array}$ & -030 & Page 1 \\
\hline $\begin{array}{l}\text { (2) Title } \\
\text { Packaging }\end{array}$ & ign Criteria for the MCO Cask & & & \\
\hline & CHANGE CONTROL RECORD & & & \\
\hline (3) Revision & (4) Description of Change - Replace, Add, and Delete Pages & Authori & ed & \\
\hline$R S$ & $\begin{array}{l}\text { (7) Revisions throughout document to } \\
\text { correlate with the procurement } \\
\text { specification written for this cask } \\
\text { system. Changes are administrative in } \\
\text { content to support the design and } \\
\text { fabrication of the packaging. A new } \\
\text { dose consequence analysis is } \\
\text { incorporated into Appendix A to } \\
\text { account for the rerack fuel scenario. } \\
\text { ECN } 625287 \text {. }\end{array}$ & $\begin{array}{l}\text { MD clements } \\
\text { M.Q.Clinumbs } \\
\text { |2|zopas }\end{array}$ & & \\
\hline 2 & $\begin{array}{l}\text { Revisions throughout document to update the } \\
\text { neutron source term, to add a table } \\
\text { describing the energy distribution of the } \\
\text { (alpha, n) neutron source, to change the } \\
\text { target for the normal condition of } \\
\text { transport free drop from an unyielding } \\
\text { surface to a more typiad enanford Site } \\
\text { surface, to change cask contamination } \\
\text { limits from DOT to Hanford Site limits, and } \\
\text { to remove the requirement for volumetric } \\
\text { inspection of the MCO closure weld. } \\
\text { ECN } 625363 \text {. }\end{array}$ & 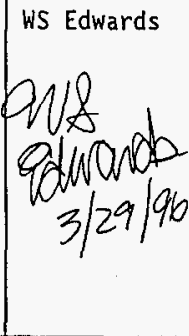 & & \\
\hline${ }^{3}$ RS & $\begin{array}{l}\text { Revisions throughout document to include } \\
\text { discussion of and requirements for transfer } \\
\text { of the Mco from the K Basins to the cold } \\
\text { Vacuum Drying Facility while filled with } \\
\text { water. The radiological and gas generation } \\
\text { source term was also updated to reflect the } \\
\text { latest cask specification revision, } \\
\text { descriptions of the current system and } \\
\text { facilities were added, leak testing and } \\
\text { containment requirements were clarified, } \\
\text { criticality requirements were updated to } \\
\text { reflect new Federal regulations, } \\
\text { contamination limits were returned to DOT } \\
\text { limits, and several other requirements were } \\
\text { updated. ECN } 630853 \text {. }\end{array}$ & 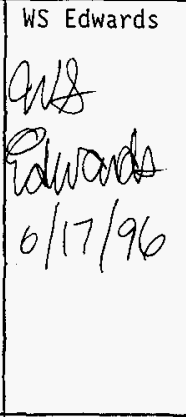 & & \\
\hline & & & & \\
\hline & & & & \\
\hline & & & & \\
\hline & & & & \\
\hline & & & & \\
\hline & & & & \\
\hline & & & & \\
\hline & & & & \\
\hline
\end{tabular}


1.0 INTRODUCTION ....................... 1

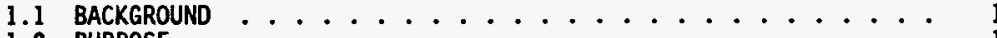

1.2 PURPOSE

1.3 SYSTEM DESCRIPTION $\ldots \ldots \ldots \ldots \ldots \ldots \ldots \ldots$

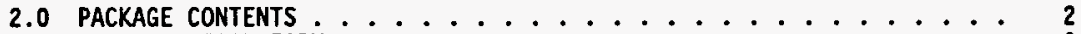

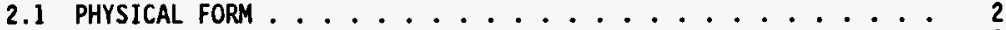



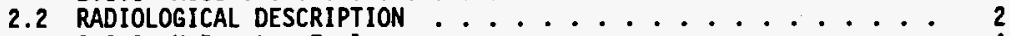

2.2.1 N Reactor Fuel . . ...............44

2.3 CHEMICAL CONSTITUENT SOURCE TERM ............ 7

2.4 GAS GENERATION $\ldots \ldots \ldots \ldots \ldots \ldots \ldots \ldots . \ldots \ldots$

2.5 THERMAL DESCRIPTION ................. 8

2.5.1 Thermal Source Term ............. 8

2.5.2 MCO Surface Emittance ............. 8

2.5.3 Payload and MCO Thermal Mass ............ 8

2.5.4 MCO Dimensions and Gross Weight .......... 8

2.5.5 Maximum MCO Temperature ............8 8

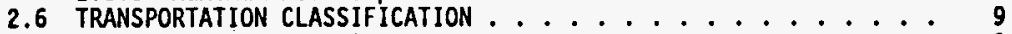

2.7 FISSILE CLASSIFICATION ................

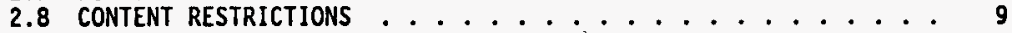

3.0 FACILITY OPERATIONS ...................... 10

3.1 ORIGINATING SITE--K BASINS $\ldots \ldots \ldots \ldots$

3.2 INTERMEDIATE SITE--CVD FACILITY . ........... 10

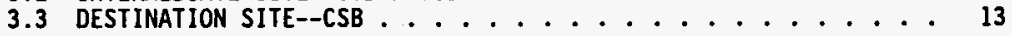

4.0 PACKAGING/TRANSPORT SYSTEM DESIGN .............. 13

4.1 GENERAL . . . . ................ 13

4.2 PACKAGING DESIGN CRITERIA . . . ........... 13

4.2.1 Packaging Materials ............. 13

4.2.2 Fabrication Methods .............. 15

4.2.3 Packaging Dimensions ............... 15

4.2.4 Maximum Gross Weight ........... 16

4.2.5 Lifting and Tiedown Attachments ......... 16

4.2.6 Gas Generation and Venting ............ 16

4.2 .7 Loading .................. 16

4.2 .8 Draining ................ 16

4.2.9 Water Circulation ............. 17

4.2 .10 Closure ..................... 17

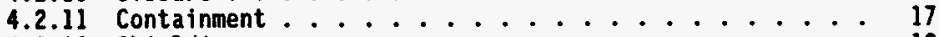

4.2.12 Shielding................. 18

4.2.13 Maintenance ................ 18

4.2.14 Life Cycle ................ 18

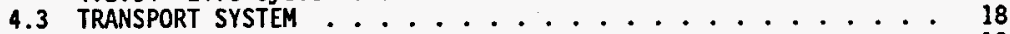

4.3.1 General ................. 18

4.3.2 Truck Transport System . . . . . . . . . . . 19

4.3.3 Additional Requirements ............. 19

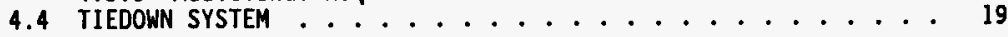




\section{CONTENTS (cont.)}

5.0 GENERAL REQUIREMENTS ....................... 20

5.1 TRANSPORTATION SYSTEM .................. 20

5.1.1 Normal Conditions of Transfer ........... 20

5.1 .2 Accident Conditions ............... 23

5.2 ALARA ..................... 26

5.3 QA . . . . . . . . . . . . . . . . . 26

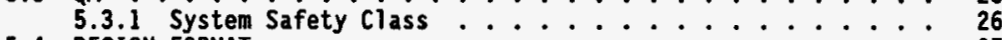

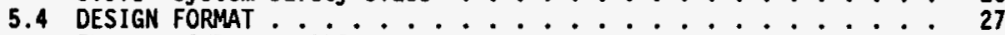

5.5 ENVIRONMENTAL COMPLIANCE .................. 27

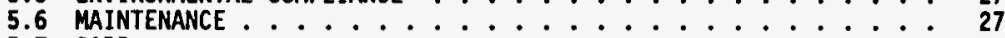

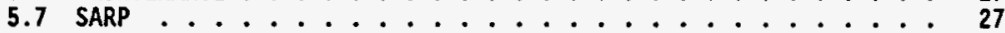

6.0 REFERENCES ........................... 27 APPENDICES

A SAFETY CLASSIFICATION FOR THE K BASIN CASK . . . . . . . . . . . A-1

B ONSITE SARP TABLE OF CONTENTS .................... B-1

\section{LIST OF FIGURES}

1 MCO Preliminary Design Description . . . . . . . . . . . . 3

2 N Reactor Fuel Assembly ...................... 5

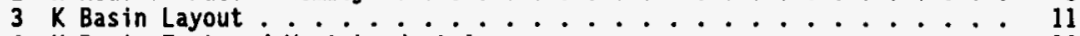

$4 K$ Bas in East and West Loadout Area . . . . . . . . . . . . . . . . . 12

5 Canister Storage Building Loadout Area . . . . . . . . . . . . . . 14

\section{LIST OF TABLES}

1 Worst-Case Source Term for N Reactor Fuel . . . . . . . . . . . . . . 4

2 Photon Source: Mark IV Fuel, $16 \%{ }^{240} \mathrm{Pu}, 13$ Years Decay ........ . 6

3 Energy Distribution of Neutrons from (alpha, $n$ ) Source . . . . . . 7

4 Preliminary Dimensions and Weight of the MCO . . . . . . . . . 9

5 External Cask Contamination Limits . . . . . . . . . . . . 10

6 Load Factors for Tiedown Systems . . . . . . . . . . . . . . . 20

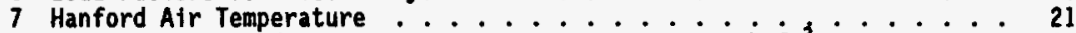

8 Maximum Solar Radiation Received from the Sun $\left(\dot{B T U} / \dot{h}-\mathrm{ft}^{2}\right) \ldots \ldots$ 


\section{LIST OF TERMS}

$\begin{array}{ll}\text { ALARA } & \text { as low as reasonably allowable } \\ \text { ANSI } & \text { American National Standards Institute } \\ \text { ARF } & \text { airborne release fraction } \\ \text { ASME } & \text { American Society of Mechanical Engineers } \\ \text { ASTM } & \text { American Society for Testing and Materials } \\ \text { CFR } & \text { Code of Federal Regulations } \\ \text { Ci } & \text { curie } \\ \text { CSB } & \text { Canister Storage Building } \\ \text { CVD } & \text { Cold Vacuum Drying } \\ \text { EDE } & \text { effective dose equivalent } \\ \text { g } & \text { gram } \\ \text { HRCQ } & \text { Highway Route Controlled Quantity } \\ \text { IAEA } & \text { International Atomic Energy Agency } \\ \text { in. } & \text { inch } \\ \text { kg } & \text { kilogram } \\ \text { km } & \text { kilometer } \\ \text { kPa } & \text { kilopascal } \\ \text { L/min } & \text { liters per minute } \\ \text { Ib } & \text { pound } \\ \text { m } & \text { meter } \\ \text { MCO } & \text { Multiple Canister Overpack } \\ \text { mR/h } & \text { milliroentgen per hour } \\ \text { mrem/h } & \text { millirem per hour } \\ \text { MTU } & \text { metric tons of uranium } \\ \text { oz } & \text { ounce } \\ \text { PDC } & \text { packaging design criteria. } \\ \text { pSi } & \text { pounds per square inch } \\ \text { QA } & \text { quality assurance } \\ \text { SARP } & \text { Safety Analysis Report for Packaging } \\ \text { SNF } & \text { spent nuclear fuel } \\ \text { SPR } & \text { Single Pass Reactor } \\ \text { Pmm } & \text { micrometer } \\ \text { W } & \text { watt }\end{array}$


WHC-SD-TP-PDC-030

Rev. 3

This page intentionally left blank. 
WHC-SD-TP-PDC-030 Rev. 3

PACKAgING DESIGN CRITERIA FOR THE MCO CASK

\subsection{INTRODUCTION}

\subsection{BACKGROUND}

Approximately 2,100 metric tons of unprocessed, irradiated nuclear fuel elements are presently stored in the $K$ Basins (including possibly 700 additional elements from PUREX, $N$ Reactor, and 327 Laboratory). The basin water, particularly in the $K$ East Basin, contains significant quantities of dissolved nuclear isotopes and radioactive fuel corrosion particles. To permit cleanup of the $K$ Basins and fuel conditioning, the fuel will be transported from the $100 \mathrm{~K}$ Area to a Canister Storage Building (CSB) in the 200 East area. In order to initiate $K$ Basin cleanup on schedule, the two-year fuel-shipping campaign must begin by December 1997.

\subsection{PURPOSE}

The purpose of this packaging design criteria (PDC) is to provide criteria for the design, fabrication, and use of a packaging system to transport large quantities of irradiated nuclear fuel elements positioned in Multiple Canister Overpacks (MCO), within the boundaries of the Hanford Site. The PDC will provide the basis for the system design and fabrication. It also sets the transportation safety criteria that the design will be evaluated against in the Safety Analysis Report for Packaging (SARP) (onsite). The approved PDC provides a formal set of standards early in the design and analytic process, and prevents costly delays later due to multiple and iterative interpretations of the requirements. The PDC will be approved by Westinghouse Hanford Company, including Quality Assurance, Safety, the Safety and Environmental Advisory Council, and the U.S. Department of Energy, Richland Operations Office.

\subsection{SYSTEN DESCRIPTION}

This packaging design criteria defines the requirements for the MCO cask and conveyance. The term "packaging" defines the cask without the MCO and fuel elements. The term "package" defines the cask, MCO, and the fuel elements. The MCO is the cask payload because it is loaded into and out of the cask and remains at the storage destination. The MCO provides a level of containment for the fuel elements. The MCO cask provides the transportation containment barrier for the payload, as defined in this PDC.

Fuel elements will be removed from their current canister storage containers in the $K$ Basins, cleaned, and placed in baskets. The baskets will then be top loaded into the MCO, which is located in the cask in the pool. The MCO shield plug/lid will be placed on the MCO, the package lifted out of the pool, the cask lid installed, and the package placed on its trailer for transfer to a Cold Vacuum Drying (CVD) Facility in the $100 \mathrm{~K}$ Area. Cold vacuum drying involves water circulation around the outside of the $M C O$ and 
vacuum drying of the MCO. The MCO package will be transported from the $K$ Basins to the CVD Facility with water covering the spent fuel inside the MCO. The MCO may be sealed either at the $K$ Basins or the CVD Facility. After cold vacuum drying is complete, the MCO package will be transported to the CSB for further fuel conditioning and storage.

\subsection{JUSTIFICATION}

At present, no packagings licensed by either the U.S. Nuclear Regulatory Commission or the U.S. Department of Energy are capable of transporting the $K$ Basins spent nuclear fuel (SNF) within the constraints of the project requirements. The project requires that the SNF be moved in MCOs. The only onsite packaging system that may be compatible is the three-well-raflcar system, which is geometrically incompatible with the MCOs. A packaging and transportation system must be developed that can transport the irradiated fuel within current safety standards, protect the environment, and be economicaliy and operationally feasible.

\subsection{PACKage CONTENTS}

\subsection{PHYSICAL FORM}

The payload will consist of an MCO that contains the irradiated fuel elements. MCOs are $61-\mathrm{cm}$ (24-in. [Outside diameter]) stainless steel pipe approximately $406 \mathrm{~cm}$ (160 in.) long, with the metalilic uranium fuel elements in baskets stacked inside (Figure 1 ).

\subsubsection{MCOS}

The MCO will serve as a long-term storage vessel for the irradiated fuel elements, as well as the processing vessel during conditioning processes. The MCO payload configuration is shown in Figure 1 . The MCO will be filled with water during transfer from the $K$ Basins to the CVD Facility, but will be drained and dried prior to shipment to the CSB.

\subsection{RADIOLOGICAL DESCRIPTION}

The irradiated fuel contains large quantities of fission products, such as ${ }^{137} \mathrm{Cs}$ and ${ }^{80} \mathrm{Sr}$, and actinides, such as ${ }^{239} \mathrm{Pu},{ }^{240} \mathrm{Pu}$, and ${ }^{249} \mathrm{Pu}$. To a lesser extent, it also contains cladding activation products, such as ${ }^{60} \mathrm{Co}$. A bounding worst-case radiological source term has been defined and is given in Table 1 . 
WHC-SD-TP-PDC-030 Rev. 3

Figure 1. MCO Preliminary Design Description.
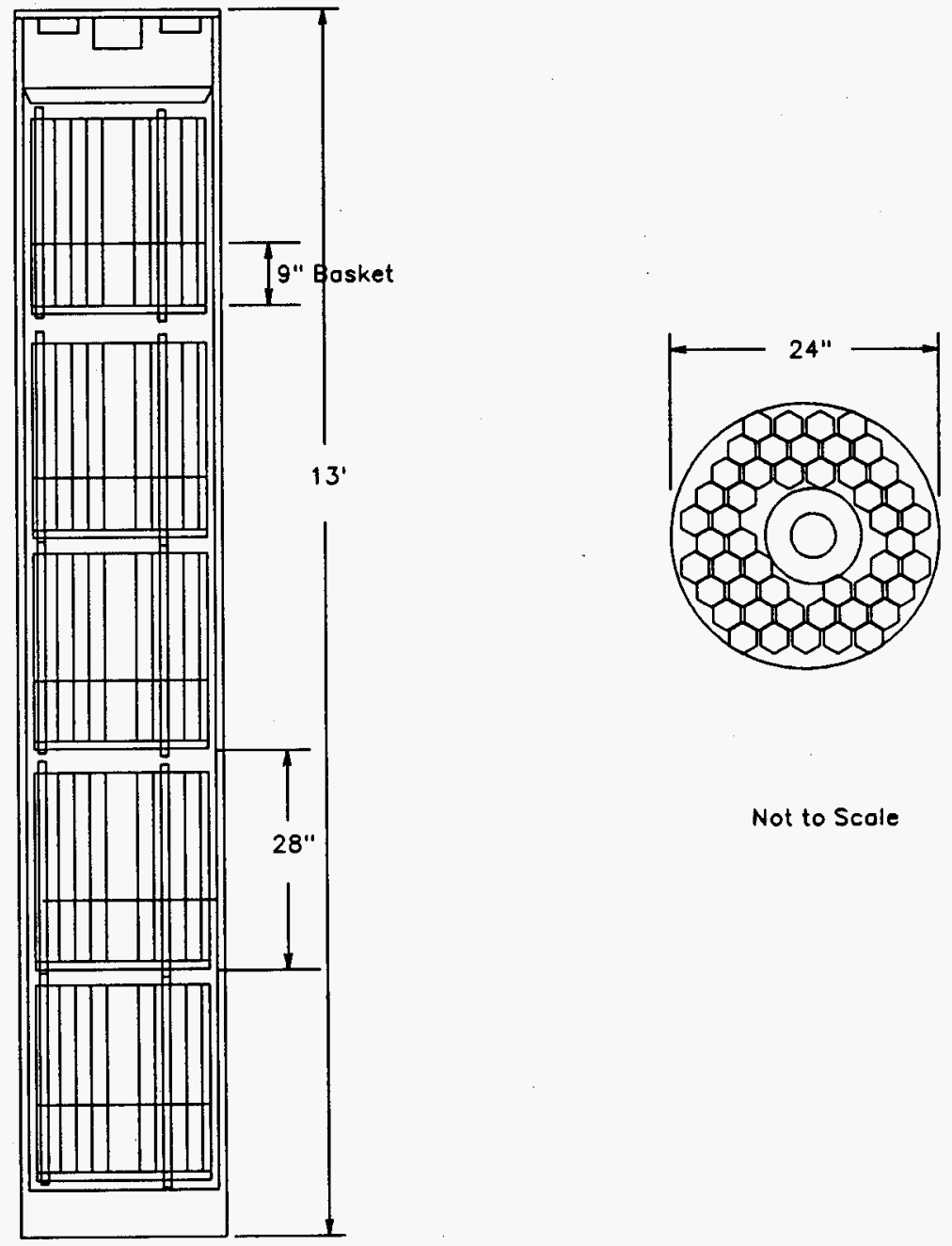

Not to Scale 


\subsubsection{N Reactor Fuel}

The bounding source term used for dose consequence is the rerack of 270 Mark IV fuel elements $66.3 \mathrm{~cm}$ (26.1 in.) long (E length [see Figure 2]). The worst anticipated $N$ Reactor fuel, for shielding and dose consequence purposes, is $0.95 \%{ }^{235} \mathrm{U}$ fuel irradiated to $16 \%{ }^{200} \mathrm{Pu} 13$ years after discharge from the reactor at the time of first fuel shipment $(12 / 31 / 97)$. Table 1 presents the anticipated worst-case activity per unit mass, per assembly, and per MCO (reracked fuel).

Table 1. Worst-Case Source Term for $\mathbf{N}$ Reactor Fuel.

\begin{tabular}{|c|c|c|c|c|c|c|c|}
\hline Isotope & $\begin{array}{l}\text { Curies } \\
\text { per ATU }\end{array}$ & $\begin{array}{l}\text { Curies per } \\
\text { single } \\
\text { assenbly }\end{array}$ & $\begin{array}{l}\text { Curies per } \\
\text { nco- }-270 \\
\text { eseembl fies }\end{array}$ & I eot ope & $\begin{array}{l}\text { Curiee } \\
\text { par nTu }\end{array}$ & $\begin{array}{l}\text { Curies per } \\
\text { eingle } \\
\text { acseably }\end{array}$ & $\begin{array}{l}\text { Cur ies per } \\
\text { nco--270 } \\
\text { sssembl les }\end{array}$ \\
\hline $\mathbf{3}_{\mathrm{H}}$ & 38.8 & 0.91 & 246 & ${ }^{144} \mathrm{Ce}$ & 2.5 & 0.06 & 16 \\
\hline $55_{\mathrm{Fe}}$ & 6.8 & 0.16 & 43 & $144 \mathrm{pr}$ & 2.5 & 0.06 & 16 \\
\hline${ }^{60} \mathrm{Co}$ & 6.5 & 0.15 & 41 & ${ }^{147} \mathrm{Pm}$ & 1084.4 & 25.5 & 6875 \\
\hline${ }^{85} \mathrm{Kr}$ & 611.5 & 14.36 & 3,877 & $151_{\text {sin }}$ & 102.7 & 2.61 & 651 \\
\hline${ }^{90} \mathrm{Sr}$ & $7,893,6$ & 185.35 & 50,045 & ${ }^{154}$ EU & 215.1 & 5.05 & 1364 \\
\hline $90_{Y}$ & $7,893.6$ & 185.35 & 50,045 & ${ }^{155} \mathrm{Eu}$ & 16.4 & 0.39 & 104 \\
\hline${ }^{106} \mathrm{RU}$ & 11.5 & 0.27 & 73 & ${ }^{238} \mathrm{Pu}$ & 147.3 & 3.46 & 934 \\
\hline${ }^{106_{\mathrm{Rh}}}$ & 11.5 & 0.27 & 73 & ${ }^{239} \mathrm{Pu}$ & 152.1 & 3.57 & 964 \\
\hline${ }^{125} \mathrm{sb}$ & $\infty .1$ & 2.33 & 628 & ${ }^{260} \mathrm{Pu}$ & 115.0 & 2.70 & 729 \\
\hline 125 $\mathrm{m}_{\mathrm{Te}}$ & 24.1 & 0.57 & 153 & $241_{\mathrm{Pu}}$ & $9,140.9$ & 214.64 & 57,953 \\
\hline${ }^{134} \mathrm{Cs}$ & 115.0 & 2.70 & 729 & $241_{\mathrm{Mm}}$ & 269.7 & 6.33 & 1710 \\
\hline${ }^{137} \mathrm{Cs}$ & $10,735.4$ & 252.08 & 68,062 & ${ }^{264} \mathrm{Cm}$ & 3.9 & 0.09 & 25 \\
\hline $137 \mathrm{~m}_{\mathrm{Ba}}$ & $10,162.8$ & 238.64 & 64,432 & & & & \\
\hline
\end{tabular}

MCO = Mult iple Canister Overpeck.

NTU = Metric tons of uranium. 
WHC-SD-TP-PDC-030 Rev. 3

Figure 2. N Reactor Fuel Assembly.

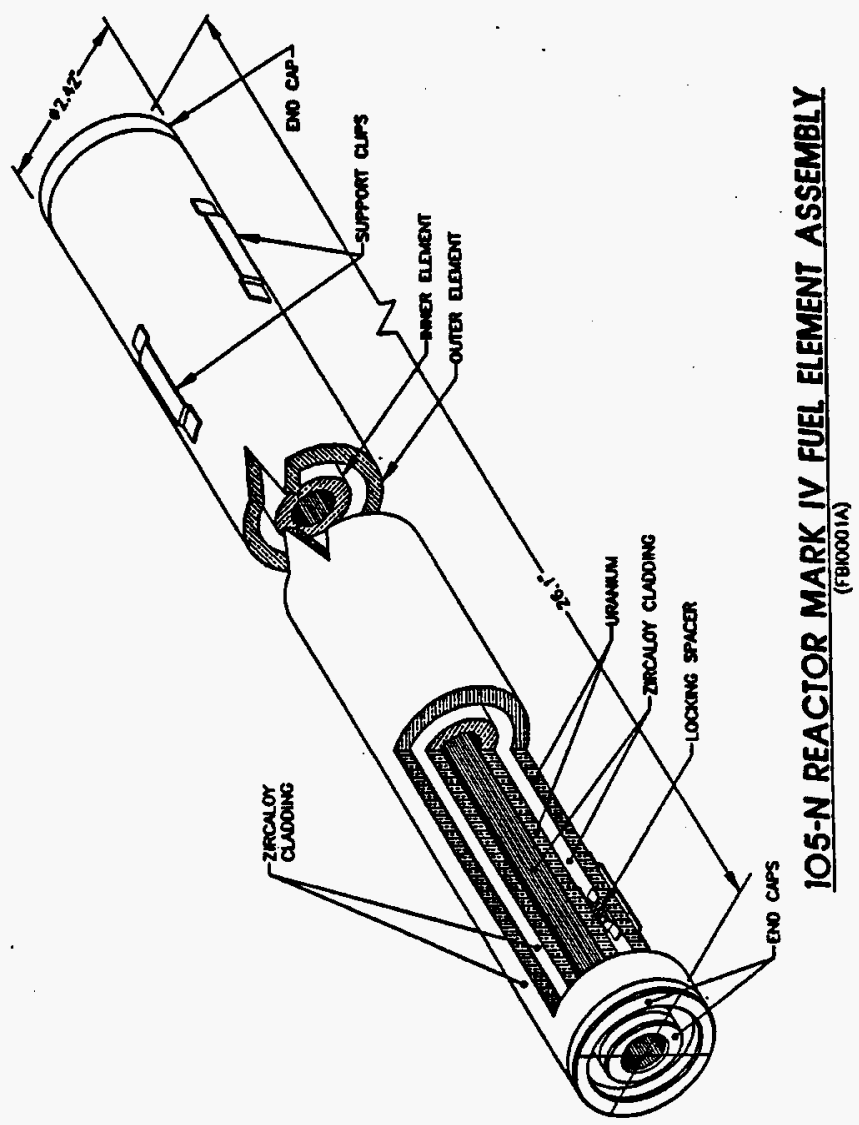


These isotopes have been used to calculate the gamma and neutron spectra generated in the fuel, as tabulated in Table 2.

Table 2. Photon Source: Mark IV Fuel, $16{ }^{260} \mathrm{Pu}, 13$ Years Decay.

\begin{tabular}{|c|c|c|c|}
\hline Energy (MeV) & Photons/eec/el enent & Photons/sec/Mco & Photons/sec/MTU \\
\hline 0.015 & $6.18 E+12$ & $1.6 \pi+15$ & $2.63 E+14$ \\
\hline 0.025 & $1.31 E+12$ & $3.54 E+14$ & $5.58 E+13$ \\
\hline 0.038 & $1.48 E+12$ & $3.99 E+14$ & $6.30 E+13$ \\
\hline 0.058 & $1.24 E+12$ & $3.35 E+14$ & $5.29 E+13$ \\
\hline 0.085 & $6.86 \mathrm{E}+11$ & $1.85 E+14$ & $2.82 E+13$ \\
\hline 0.125 & $5.10 E+11$ & $1.38 E+14$ & $2.17 E+13$ \\
\hline 0.225 & $5.80 E+11$ & $1.57 E+14$ & $2.4 \pi+13$ \\
\hline 0.375 & $2.75 E+11$ & $7.42 E+13$ & $1.17 E+13$ \\
\hline 0.662 & $8.62 E+12$ & $2.33 E+15$ & $3.67 E+14$ \\
\hline 0.850 & $2.19 E+11$ & $5.92 E+13$ & $9.34 \mathrm{E}+12$ \\
\hline 1.250 & $1.26 E+11$ & $3.41 E+13$ & $5.38 E+12$ \\
\hline 1.750 & $3.90 E+9$ & $1.05 E+12$ & $1.66 E+11$ \\
\hline 2.250 & $3.29 E+7$ & $8.88 E+9$ & $1.40 E+09$ \\
\hline 2.750 & $2.35 E+6$ & $6.34 E+8$ & $1.00 E+8$ \\
\hline 3.500 & $3.08 E+5$ & $8.31 E+7$ & $1.31 E+7$ \\
\hline 5.000 & $1.46 E+3$ & $3.94 E+5$ & $6.21 E+4$ \\
\hline 7.000 & $1.66 E+2$ & 4.50E+4 & $7.09 E+3$ \\
\hline 11.000 & $1.90 E+1$ & $5.14 E+3$ & $8.10 E+2$ \\
\hline Total & $2.26 E+13$ & $6.09 E+15$ & $9.61 E+14$ \\
\hline
\end{tabular}

mco = Multiple Cenister Overpack.

MeV = Megaelectronvolt.

MTU = Metric tons of uraniun.

The following is the neutron source for Mark IV fuel $16 \%{ }^{240} \mathrm{Pu}$ at 13 years decay (Schwarz 1995).

- The spontaneous fission source is $8.732 \mathrm{E}+05$ neutrons/sec/MTU, and the (alpha, $n$ ) neutron source is $4.861 E+05$ neutrons/sec/MTU.

- The neutron energy spectrum for the spontaneous fission source is assumed to be that for ${ }^{244} \mathrm{Cm}$, a predominant nuclide contributing to spontaneous fission. That spectrum is given by the following:

$$
f(E)=C * \exp (-E / 0.906) * \sinh (\sqrt{3.848 * E})
$$

$C$ is a normalization constant so that the integral is unity.

- The neutron energy spectrum for the (alpha, $n$ ) neutron source is given in Table 3 . 
Tabie 3. Energy Distribution of Neutrons from $(a / p h a, n)$ Source.

\begin{tabular}{|c|c|c|c|c|c|}
\hline $\begin{array}{c}\text { Upper margy } \\
\text { (MeV) }\end{array}$ & $\begin{array}{l}\text { Cumlative } \\
\text { probability }\end{array}$ & $\begin{array}{c}\text { Probebility } \\
\text { of bin }\end{array}$ & $\begin{array}{c}\text { Upper onergy } \\
\text { (MeV) }\end{array}$ & $\begin{array}{l}\text { Cumuletive } \\
\text { probability }\end{array}$ & $\begin{array}{c}\text { Probebility } \\
\text { of bin }\end{array}$ \\
\hline 0.00 & 0.00000 & 0.00000 & 2.30 & 0.59751 & 0.04128 \\
\hline 0.10 & 0.01590 & 0.01059 & 2.40 & 0.63707 & 0.03956 \\
\hline 0.20 & 0.02243 & 0.01184 & 2.50 & 0.67492 & 0.03785 \\
\hline 0.30 & 0.03398 & 0.01153 & 2.60 & 0.71137 & 0.03645 \\
\hline 0.40 & 0.04766 & 0.01371 & 2.70 & 0.74611 & 0.03474 \\
\hline 0.50 & 0.06636 & 0.01869 & 2.80 & 0.77819 & 0.03209 \\
\hline 0.60 & 0.08738 & 0.02103 & 2.90 & 0.80935 & 0.03115 \\
\hline 0.70 & 0.11044 & 0.02305 & 3.00 & 0.83863 & 0.02928 \\
\hline 0.80 & 0.13567 & 0.02523 & 3.10 & 0.86449 & 0.02586 \\
\hline 0.90 & 0.15981 & 0.02414 & 3.20 & 0.88879 & 0.02430 \\
\hline 1.00 & 0.17975 & 0.01994 & 3.30 & 0.90966 & 0.02087 \\
\hline 1.10 & 0.20062 & 0.02087 & 3.40 & 0.92664 & 0.01698 \\
\hline 1.20 & 0.22321 & 0.02259 & 3.50 & 0.94097 & 0.01433 \\
\hline 1.30 & 0.24860 & 0.02539 & 3.60 & 0.95327 & 0.01231 \\
\hline 1.40 & 0.27601 & 0.02741 & 3.70 & 0.96324 & 0.00997 \\
\hline 1.50 & 0.30405 & 0.02804 & $3.80^{\circ}$ & 0.97481 & 0.00857 \\
\hline 1.60 & 0.33349 & 0.02944 & 3.90 & 0.97928 & 0.00748 \\
\hline 1.70 & 0.36542 & 0.03193 & 4.00 & 0.98536 & 0.00607 \\
\hline 1.80 & 0.40093 & 0.03551 & 4.10 & 0.99081 & 0.00545 \\
\hline 1.90 & 0.43785 & 0.03692 & 4.20 & 0.90439 & 0.00358 \\
\hline 2.00 & 0.47666 & 0.03879 & 4.30 & 0.99720 & 0.00280 \\
\hline 2.10 & 0.51558 & 0.03894 & 4.40 & 0.99891 & 0.00171 \\
\hline 2.20 & 0.55623 & 0.04065 & 6.50 & 1.0000 & 0.00109 \\
\hline
\end{tabular}

\subsection{CHEMICAL CONSTITUENT SOURCE TERM}

The MCO containing irradiated fuel may remain water-filled during transfer from the $K$ Basins to the CVD Facility. There would be approximately $700 \mathrm{~kg}$ of water in the MCO during this transfer when all five baskets within the MCO are filled with fuel. The reracked fuel will be cold vacuum dried within the MCO prior to transfer to the CSB.

\subsection{GAS GENERATION}

Gas will be produced in the MCO by three methods: uranium corrosion, radiolysis, and fission gas release from the spent fuel. Uranium corrosion and radiolysis produce hydrogen from the reaction of water with exposed uranium from damaged fuel. For both legs of transfer, the MCO will be 
backfilled with an inert gas, such as helium, argon, or nitrogen, to minimize oxygen present, which will preclude a hydrogen burn or formation of an explosive gas mixture.

\subsection{THERMAL DESCRIPTION}

The heat source term will vary according to the type, condition, and amount of SNF to be transported. For the purposes of this PDC, the thermal source term for the payload (fuel elements) within the MCO is defined as a surface heat flux at the boundaries of the MCO. In addition, the surface emittance, thermal mass, temperature limits, etc., to be assumed for the MCO and payload assembly are defined.

\subsubsection{Thermal Source Term}

The thermal source term for the fuel will be based on the properties of the fuel and sludge loaded into the $M C O$, as well as the chemical reaction rate between any water in the MCO and the fuel.

\subsubsection{HCO Surface Emittance}

For the purpose of calculating radiative heat transfer between the MCO and the packaging system, the surface emittance of the MCO surfaces shall be assumed to be 0.25 .

\subsubsection{Payload and MCO Thermal Mass}

No credit for the thermal mass of the payload shall be taken when calculating the transient performance of the packaging system under either the normal conditions of transfer or the accident conditions, as defined in Section 5.1. The thermal mass of the MCO shell may be included.

\subsubsection{MCO Dimensions and Gross Meight}

The dimensions of the MCO and its gross weight (including the fuel elements) to be assumed for the thermal calculations is defined in Table 4.

\subsubsection{Naximum NCO Temperature}

The maximum temperature allowed for the MCO shell under normal transport conditions shall be $75^{\circ} \mathrm{C}\left(167^{\circ} \mathrm{F}\right)$.

Under the accident conditions, the temperature of the MCO shell may exceed the temperature limit for the normal conditions of transfer for a time period not to exceed 180 minutes following the fire and shall not exceed a maximum of $122^{\circ} \mathrm{C}\left(252^{\circ} \mathrm{F}\right)$. 
Table 4. Preliminary Dimensions and Weight of the MCO.

\begin{tabular}{|l|l|}
\hline \multicolumn{1}{|c|}{ Payload configuration } & \multicolumn{1}{c|}{ Figure 1 } \\
\hline MCO length & $160 \mathrm{in}$. \\
\hline MCO diameter* & $24 \mathrm{in}$. \\
\hline MCO wall & $0.5 \mathrm{in}$. \\
\hline MCO volume & $272 \mathrm{gal}$ \\
\hline Water weight & $1200 \mathrm{lb}$ \\
\hline MCO empty & $1540 \mathrm{lb}$ \\
\hline Basket weight & $500 \mathrm{lb}$ \\
\hline MCO Shield Plug weight & $1230 \mathrm{lb}$ \\
\hline Fuel and cladding & $15,050 \mathrm{lb} / \mathrm{MCO}$ \\
\hline Total MCO weight--dry & $18,320 \mathrm{lb}$ \\
\hline Total MCO weight--wet & $19,520 \mathrm{lb}$ \\
\hline
\end{tabular}

\subsection{TRANSPORTATION CLASSIFICATION}

For onsite transportation purposes, the irradiated fuel payload of the packaging is considered Type B, Highway Route Controlled Quantity (HRCQ), fissile, spent fuel. The transport will be administratively controlled based on the potential dose consequences associated with the payload.

\subsection{FISSILE CLASSIFICATION}

The payload shall be classified as fissile material for transportation. The maximum fissile content per cask is $60,036 \mathrm{~g}$ for the worst-case Mark IV fuel rerack scenario. A criticality analysis will be performed to determine the criticality transport index of the shipment in the SARP. For the purposes of this PDC, the criticality transport index is assumed to be $100\left(" N^{n}=0.5\right)$.

\subsection{CONTENT RESTRICTIONS}

The MCO cask payload shall be limited to nuclear fuel elements cleaned and placed in baskets that have been loaded into an MCO. As stated in the Bounding Particulate Contents of a Multi-Canister Overpack (Pajunen 1996), each MCO will contain no more than $300 \mathrm{~kg}$ of sludge. 


\subsection{FACILITY OPERATIONS}

\subsection{ORIGINATING SITE--K BASINS}

Loading of the MCO and packaging shall take place in the loadout pits of the $K$ East and $K$ West Basins (Figure 3 ). This facility is limited in space and lifting capabilities. The MCO is placed into the MCO cask prior to the loading of the reracked fuel baskets into the MCO. The fuel baskets shall be prepared, as necessary, for the conditioning process prior to being loaded into the $\mathrm{MCO}$. Further conditioning of the fuel, such as vacuum drying, may take place with the MCO in the cask. The package shall be mounted on the transfer vehicle before leaving the basin. The exterior package contamination limits must be met, as shown in Table 5, prior to transportation. Prior to reuse of the cask, the cask internal cavity shall be decontaminated to less than 100 times the removable contamination limits set forth in Table 5. Figure 4 provides a sketch of the $K$ East and $K$ West loading areas, which are identical. Limited modifications of the loading area may be necessary to improve the fuel-loading and package-handling capabilities of the facility. The cask lid shall be installed before the package leaves the $K$ Basins.

Table 5. External Cask Contamination Limits.

\begin{tabular}{|c|c|c|}
\hline \multirow{2}{*}{ Cont aminant } & \multicolumn{2}{|c|}{ Maximum permissible limits } \\
\hline & $\mathrm{ACi} / \mathrm{cm}^{2}$ & $\operatorname{dpm} / \mathrm{cm}^{2}$ \\
\hline 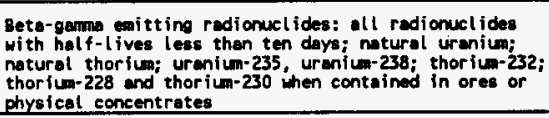 & $10^{-5}$ & 22 \\
\hline All other alphe emitting radionuclides & $10^{-6}$ & 2.2 \\
\hline
\end{tabular}

\subsection{INTERMEDIATE SITE--CVD FACILITY}

Draining of the water from the MCO, vacuum drying of the MCO, and sealing the MCO lid/shield plug onto the MCO will occur at the CVD Facility. The CVD Facility may be located in the $K$ Basins facilities or within a separate building in the $100 \mathrm{~K}$ Area. If a CVD Facility is built away from the $K$ Basins, the package will arrive at the CVD Facility on the trailer. The CVD Facility will perform all operations while the package is on the trailer. While at the CVD Facility, the MCO cask lid will be removed, and the MCO iid/shield plug will be sealed onto the MCO, if it was not sealed before it left the $K$ Basins. The MCO will then be drained of water and vacuum dried. The cask lid will be installed before final shipment to the CSB. 
WHC-SD-TP-PDC-030 Rev. 3

Figure 3. K Basin Layout.

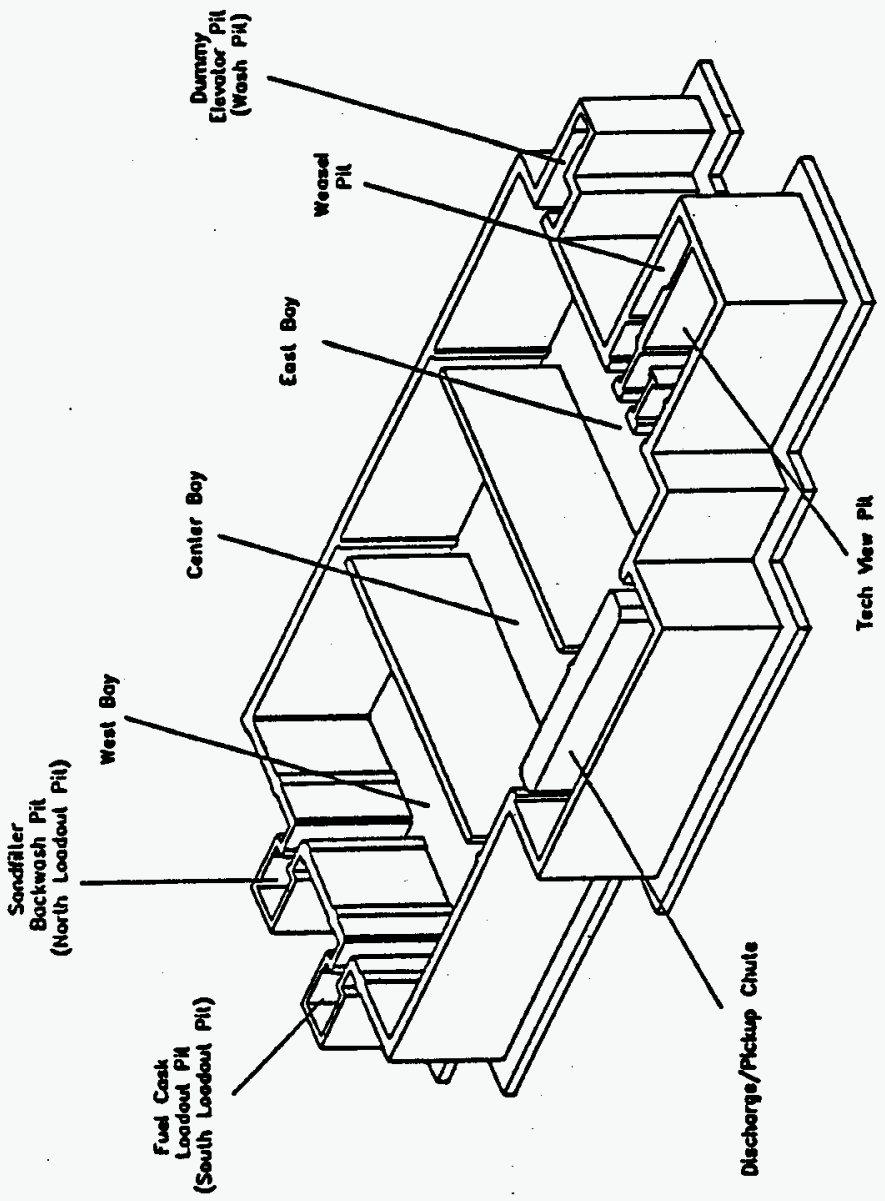


WHC-SD-TP-POC-030 Rev. 3

Figure 4. K Basin East and West Loadout Area.

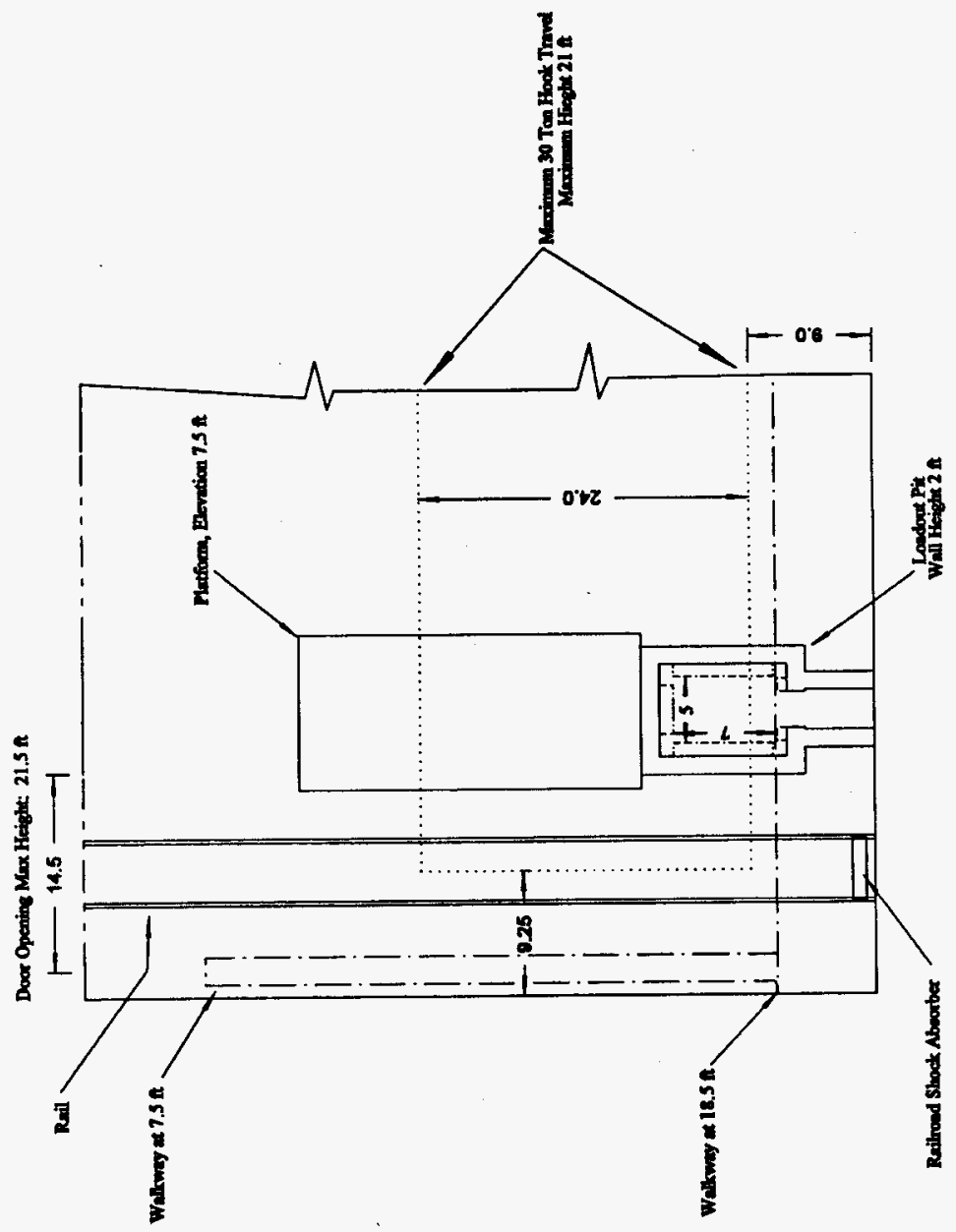


WHC-SD-TP-PDC-030 Rev. 3

\subsection{DESTINATION SITE--CSB}

Off-loading of the package shall take place at the CSB (Figure 5) in the 200 East Area. This activity shall involve the removal of the MCO from the package. The packaging shall also be decontaminated to Table 5 limits and inspected, as needed, before transport back to the $K$ Basins.

\subsection{PACKAGING/TRANSPORT SYSTEM DESIGN}

\subsection{GENERAL}

The packaging shall be approved for use within the boundaries of the Hanford site. It will be authorized to transfer Type B, HRCQ of fissile radioactive material in the form of irradiated fuel assemblies. A SARP shall be written to demonstrate the safety of the transfer through a combination of cask performance and administrative controls as per the Report on Equivalent Safety for Onsite Packaging and Transportation (WHC 1994). The SARP will include the evaluation of the packaging system to provide containment, shielding, and subcriticality for the payload during normal (Section 5.1.1) and accident (Section 5.1.2) conditions. The packaging and transportation shall be performed in accordance with WHC-CM-2-14, Hazardous Material Shipping and Packaging Manual. Approval of the SARP provides authorization for onsite transport.

The packaging shall be designed to meet all Hanford Site "Master Safety Rules" referenced in WHC-CM-1-10, Safety Manual. The packaging shall also be designed to meet Occupational Safety and Health Administration standards per 29 CFR 1910 during normal operations, including loading, transport, unloading, and decontamination.

\subsection{PACKaging DESIGN CRITERIa}

The MCO cask shall be designed as a reusable system capable of being loaded and unloaded both in air and underwater. The MCO cask shall be capable of carrying one MCO. The MCO cask design shall be such that the MCO may be sealed after being loaded into the packaging cavity. The cask will be top loaded. The cask design shall allow draining of water from the cask cavity prior to or after transport.

Package performance requirements will be verified through analysis, or a combination of analytical and test methods, for bounding case scenarios within the SARP.

\subsubsection{Packaging Materials}

The structural containment boundary materials for the packaging shall comply with material requirements identified in NUREG/CR-3854, Fabrication 
WHC-SD-TP-PDC-030 Rev. 3

Figure 5. Canister Storage Building Loadout Area.

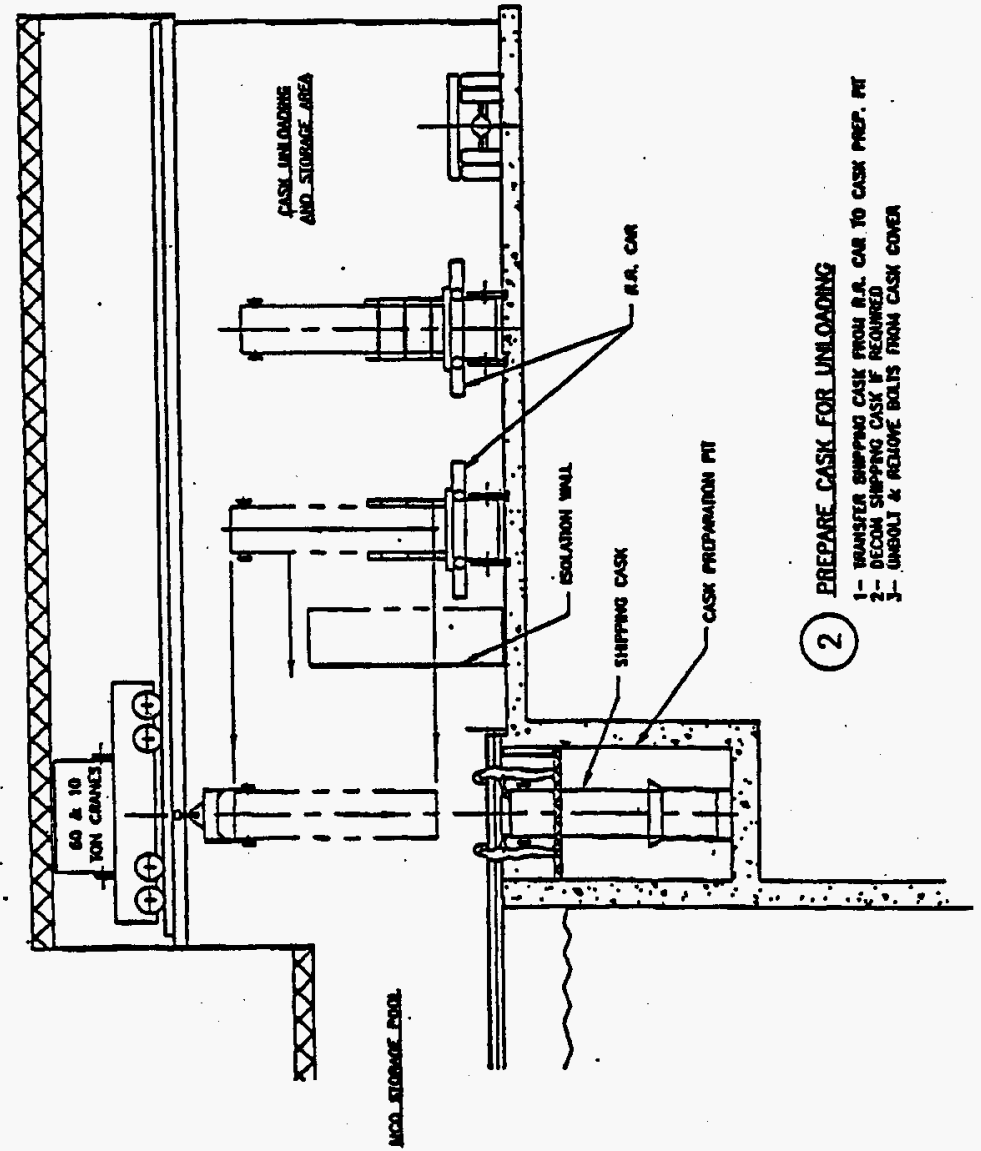


WHC-SD-TP-PDC-030 Rev. 3

Criteria for Shipping Containers (Fischer and Lai 1985). The materials of construction shall meet the fracture toughness requirements of Regulatory Guide 7.11 (NRC 1991a) or Regulatory Guide 7.12 (NRC 1991b), as applicable.

All materials shall be American Society of Mechanical Engineers (ASME) or American Society for Testing and Materials (ASTM)-certified materials or other national or industrial standards for materials other than steel or stainless steel that have been approved by the design authority. The materials shall be compatible with or provide adequate resistance to the corrosive effects of materials (liquids, vapors, gases, and solids) that they will be in contact with throughout their life cycle ( 20 years). The materials shall also be selected to minimize chemical-galvanic reactions between payload components and the packaging.

\subsubsection{Fabrication Methods}

Fabrication criteria for a Category I packaging, as delineated in NUREG/CR-3854 (Fischer and Lai 1985), shall be followed. Fabrication of the packaging shall be performed in accordance with ASME (1992) Section III, as required by NUREG/CR-3854.

Welding criteria for a Category I packaging, as delineated in NUREG/CR-3019 (Monroe et a1. 1984), shall be followed. All welds and weld joints shall be examined per ASME (1992) Section III. Welds shall be inspected in accordance with the examination methods of ASME (1992) Section V, except as modified by the requirements of Section III. Welders shall be qualified per ASME (1992) Section IX.

All welds shall be sufficiently smooth to enable easy decontamination. The design shall consider avoiding potential contamination traps to the greatest extent practicable. All containment welds shall be inspected per ASME Section III, Subsection NB, requirements.

Decontamination of all external surfaces will be required to meet Table 5 limits. Surface areas that may contact radioactive materials shall be designed for ease of decontamination.

All of the above requirements apply to the fabrication of the MCO and the MCO Cask. However, an exception from the above criteria may be taken for the MCO. Examination of the MCO closure may be limited to liquid penetrant or magnetic particle examination of the root and final passes if the MCO closure is designed as a partial penetration weld that does not take credit for the thickness of the root pass.

\subsubsection{Packaging Dimensions}

The dimensions for the internal cavity of the packaging must be sufficient to accommodate the $M C O$. The MCO concept maximum dimensions are $406 \mathrm{~cm}$ (160 in.) long by $61 \mathrm{~cm}$ (24 in.) in diameter.

The maximum dimensions for the packaging exterior shall be based on the handling limits of the K Basins and CSB, shown in Figures 4 and 5 . 


\subsubsection{Maximum Gross Melght}

The weight of a package fully loaded with reracked fuel, water, etc., shall not exceed $60,000 \mathrm{lb}(27,210 \mathrm{~kg})$. The package shall be configured to be handled with the $K$ Basin crane. The maximum lifting capacity of this crane is 30 tons $(27,210 \mathrm{~kg})$.

\subsubsection{Lifting and Tiedown Attachments}

The lifting attachments for the packaging shall be capable of lifting three times the total suspended weight without generating a combined stress or maximum tensile stress at any point in the load path in excess of the corresponding minimum yield strength of their materials of construction. The lifting attachments shall be compatible with the cranes in the $K$ Basins loadout area, CSB cranes, and portable cranes to permit field lifting of the packaging.

If the tiedown attachments are a structural part of the packaging, they shall be designed to withstand a force of ten times the package weight in the forward and aft directions; five times the gross package weight in the lateral directions; and two times the package weight in the vertical directions without yielding.

\subsubsection{Gas Generation and Venting}

The packaging design shall incorporate features that will prevent the concentration of hydrogen gas in the cask annulus from exceeding $5 \%$ by volume during a period of time twice the maximum expected shipping time (NRC 1984). If hydrogen concentration in the $\mathrm{MCO}$ is above the $5 \% 1 \mathrm{imit}$, appropriate administrative and safety precautions will be provided.

The packaging design shall incorporate vents for sampling the cask cavity. Any vents that are incorporated in the design must be capable of being closed and made leaktight during normal transport conditions. During and subsequent to accident conditions, the release of materials from the package, including the venting system, shall not exceed the limits set in Section 5.1.2.

\subsubsection{Loading}

The packaging shall be capable of being loaded underwater or in air. The packaging shall be capable of being top-loaded with an empty or full MCO.

\subsubsection{Draining}

The packaging shall be outfitted with a drain port and high port vent that will permit removal of liquids from the cask cavity with or without a fully loaded MCO loaded into the cask. The drain port and high port vent shall be capable of being opened and closed using remote handing equipment. 


\subsubsection{Water Circulation}

The packaging shall be equipped with features that permit circulation of a minimum of $76 \mathrm{~L} / \min (20 \mathrm{gpm}), 50^{\circ} \mathrm{C}\left(122{ }^{\circ} \mathrm{F}\right)$, water through the package/MCO annulus for the cold vacuum drying process. This feature shall provide a uniform water temperature flow around the MCO. The system shall provide double shut-off quick release interfaces to the inlet and outlet ports on the cask. The design shall include features that will retain the MCO in the packaging for all normal and off-normal pressures in the annulus.

\subsubsection{Closure}

Each packaging closure shall be securely closed with a positive fastening device that cannot be opened unintentionally. The cask closure shall be simple to install, leak testable, and reliable. The cask payload cavity shall be provided with the capability to be filled and purged with inert gas.

\subsubsection{Containment}

The packaging shall be designed so that during normal transfer conditions from the $K$ Basins to the CVD Facility (Section 5.1.1.1), the package prevents leakage from exceeding Section 5.1.1.3 requirements, as demonstrated through testing and/or analysis. Linear-elastic analysis may be performed to demonstrate maintenance of the leakage rate after the normal transfer conditions. ASME (1992) Section III, Service Level A stress allowables shall be used for analytical acceptance.

The packaging shall be designed so that during normal transfer conditions from the CVD Facility to the CSB (Section 5.1.1.2), the package remains leaktight, as demonstrated through testing and/or analysis. Linear-elastic analysis may be performed to demonstrate maintenance of the leakage rate after the normal transfer conditions. ASME (1992) Section III, Service Level A stress allowables shall be used for analytical acceptance.

The cask system shall also be designed such that, during accident conditions (Section 5.1.2) the package maintains a single confinement barrier for the MCO, as demonstrated by analysis and/or testing. Elastic-plastic analysis may be performed to demonstrate maintenance of confinement after the accident conditions. ASME (1992) Section III, Service Level D stress allowables shall be used for analytical acceptance. Energy absorbed by the package during the drop is accounted for based on elastic-plastic analysis. During the fire scenario, the MCO cask seals may deteriorate such that loss of the cask containment seal occurs. loaded.

The cask shall be designed so that it is leakage rate testable once 
WHC-SD-TP-PDC-030 Rev. 3

\subsubsection{Shielding}

As low as reasonably achievable (ALARA) principles will be the limiting factor for the design dose rate of the package. The packaging and closures (lid, vent ports, leak test ports, etc.) shail be designed to ensure that they provide adequate shielding, as defined by Sections 5.1.1.4 and 5.1.2.4.

\subsubsection{Haintenance}

The packaging and ancillary components shall be designed to minimize maintenance or testing requirements. Features requiring maintenance shall be designed in accordance with ALARA principles using the guidance found in WHC-SD-GN-DGS-3011, Radiological Design Guide.

\subsubsection{Life Cycle}

The packaging shall be capable of being reused a minimum of 1,000 times. The MCO is used only one time for transportation and is the long-term storage container. Additionally, the packaging shall have a minimum transport service life of 20 years. Design features of the packaging shall minimize maintenance, refurbishing, and decontamination procedures required for packaging reuse. Features requiring refurbishment prior to reuse shall be designed in accordance with ALARA principles, as per WHC-SD-GN-DGS-30I1.

The SARP will address the necessary maintenance requirements, such as inspections and part replacements, to allow for the safe and effective reuse of the cask.

\subsection{TRANSPORT SYSTEM}

\subsubsection{General}

The transport operation involves loading the irradiated fuel into the MCO and packaging at the $100 \mathrm{~K}$ East and West Basins, installing the 1 id, and securing the package to a transport vehicle before shipment of the fuel. Figure 4 provides a sketch of the $100 \mathrm{~K}$ East and West loading areas. Limited modifications to the $K$ East and $K$ West loading areas, which are identical, may be necessary to facilitate loading and handling of the package.

Transfer of the package from the $K$ Basins to the CVD Facility in the $100 \mathrm{~K}$ Area for cold vacuum drying will be by truck/trailer. The maximum total loaded transfer distance will be approximately $0.8 \mathrm{~km}(0.5 \mathrm{mi})$. If not sealed at the $K$ Basins, the MCO lid will be sealed to the MCO once at the CVD Facility. Other CVD Facility operations include completely draining the MCO of water, vacuum drying the fuel, and reinstalling the cask 1 id.

Transport of the package from the $100 \mathrm{~K}$ Area to the CSB in the 200 East Area for further conditioning and storage will be by truck/trailer. The total loaded transport distance will be approximately $16 \mathrm{~km}$ (10 $\mathrm{mi}$ ). 


$$
\text { WHC-SD-TP-PDC-030 , Rev. } 3
$$

The transportation campaign shall use existing onsite transport vehicles, if possible. Modifications required for adaptation of the transport vehicle shall be minimized.

\subsubsection{Truck Transport System}

The transportation system may use a specially equipped trailer capable of transporting a minimum of one package per shipment. This trailer shall meet all applicable U.S. Department of Transportation standards and be capable of being pulled by tractors presently available for use on the Hanford Site. The trailer shall be a National Highway Traffic Safety Administration-registered trailer and meet all requirements of the enhanced Commercial Vehicle Safety Alliance inspection. Specific standards for the trailer to ensure compatibility with the $K$ Basins and CSB facilities are as follows.

- The maximum gross weight per axle for a fully loaded tractor/trailer combination shall not exceed $9,100 \mathrm{~kg}(20,000 \mathrm{lbs})$.

- The maximum width of the tractor/trailer combination shall not exceed $3.96 \mathrm{~m}(13 \mathrm{ft})$.

- Dimensions with the cask system attached in a horizontal or vertical configuration shall allow access to the interfacing facilities.

- The height of the trailer bed shall be limited so that the combined height of the cask, with tiedowns and impact limiters, if used, shal1 not exceed $6.15 \mathrm{~m}$ (20 ft $2 \mathrm{in.}$ ) when mounted to the trailer.

- The trailer shall be equipped with tiedown points sufficient to secure the cask in accordance with the requirements set forth in Section 4.4 .

\subsubsection{Additional Requirements}

To prevent the trailer from tipping over during normal transport, the trailer shall be designed in accordance with ANSI Standard N14.30 (ANSI 1992). That standard requires the center of gravity of the trailer and its load to be within $5.08 \mathrm{~cm}(2.0 \mathrm{in.})$ of the transverse center of the trailer and requires the height of the center of gravity to be less than $120 \%$ of the trailer track (center-to-center width of the trailer tire group).

\subsection{TIEDOWN SYSTEM}

An engineered tiedown system shall be used to secure the packaging system to the transport vehicle(s). The tiedown system shall meet the requirements and be designed per the International Atomic Energy Agency (IAEA) Safety Series 37 (IAEA 1990). The tiedown attachments for those requirements shall be capable of resisting the forces for road, as described in Table 6 . 
Table 6. Load Factors for Tiedown Systems.

\begin{tabular}{|c|c|c|c|}
\hline Mode & Longitudinal & Lateral & Vertical \\
\hline Road & $+2 g$ & $+/-1 g$ & $3 g$ down, $2 g$ up \\
\hline
\end{tabular}

Consideration shall be given to tiedown methods (such as remote operations or permanent systems integral to the packaging and transport vehicle) to maximize the distance and/or minimize the time spent near the payload.

\subsection{GENERAL REQUIREMENTS}

\subsection{TRANSPORTATION SYSTEN}

There are two distinct phases of transportation of the MCO cask package. The first phase is transfer from the $K$ Basins to the CVD Facility with an MCO loaded with fuel and filled with water. The MCO lid may or may not be sealed onto the MCO during this phase. The second phase is transfer from the CVD Facility to the CSB with a sealed MCO loaded with fuel, but almost empty of water due to the cold vacuum drying process. This section address both distinct phases of transfer.

\subsubsection{Normal Conditions of Transfer}

For conditions normally incident to transfer, the SARP shall evaluate the packaging design for its ability to maintain containment, shielding, and nuclear criticality control when subjected to the following conditions. This section lists normal conditions of transfer for transfer of the package from $K$ Basins to the CVD Facility and from the CVD Facility to the CSB. Conditions unique to the transfer of the package from the $K$ Basins to the CVD Facility are identified in Sections 5.1.1.1, while conditions unique to the transfer of the package from the CVD Facility to the CSB are identified in Section 5.1.1.2.

- Environmental Conditions. The design temperature limits for the individual components, parts, and materials of the package shall be determined by analyses and/or testing. The analyses and/or tests shall be based upon the conditions listed below. The operational temperatures sha11 be shown to not exceed the design limits. Hanford Site environmental conditions are derived from WHC-SD-TP-RPT-004 (Fadeff 1992). The ambient temperatures at the Hanford Site for the peak sumer month are tabulated in Table 7. 
Table 7. Hanford Air Temperature.

\begin{tabular}{|c|c|c|c|c|c|}
\hline Tilue & $\begin{array}{c}\text { Temperature } \\
\text { (" } \mathrm{F}) \\
\end{array}$ & Tine & $\begin{array}{c}\text { Texpereture } \\
\text { (EF) }\end{array}$ & Tive & $\begin{array}{c}\text { Temperature } \\
\left({ }^{\circ} F\right)\end{array}$ \\
\hline 12 a.m. & 82 & o a.m. & 85 & 4 . .m. & 115 \\
\hline 2 . . . . & 78 & 10 . . . & 97 & 6 p.m. & 113 \\
\hline 4 a. & $\pi 5$ & 12 p. & 103 & Q p.n. & 100 \\
\hline 6 a. & 74 & 2 p.m. & 111 & 10 p.m. & 89 \\
\hline & & & & 12 •. m. & 82 \\
\hline
\end{tabular}

- Maximum heat generation rate of worst-case source from Section 2.2 plus maximum solar heat load (see Table 8) plus maximum air temperature of $46^{\circ} \mathrm{C}\left(115^{\circ} \mathrm{F}\right)$

- Minimum air temperature of $-33^{\circ} \mathrm{C}\left(-27^{\circ} \mathrm{F}\right)$ plus maximum heat generation rate from worst-case source in Section $\mathbf{2 . 2}$

- Minimum air temperature of $-33^{\circ} \mathrm{C}\left(-27^{\circ} \mathrm{F}\right)$ and zero heat generation rate.

Table 8. Maximum Solar Radiation Received from the Sun (BTU/h- $\left.\mathrm{ft}^{2}\right)$.

\begin{tabular}{|c|c|c|c|c|c|c|c|c|c|}
\hline \multirow{2}{*}{ Time } & \multicolumn{8}{|c|}{ Vertical surfaces facing } & \multirow{2}{*}{$\begin{array}{l}\text { Horizantal } \\
\text { surface } \\
\text { facing us }\end{array}$} \\
\hline & $\mathbf{N}$ & ME & E & SE & $\mathbf{s}$ & su & $H$ & WH & \\
\hline $4 . .6$. & 0 & 0 & 0 & 0 & 0 & 0 & 0 & 0 & 0 \\
\hline $6 . .6$. & 57 & 192 & 211 & 105 & 17 & 17 & 17 & 17 & 64 \\
\hline 8 :.m. & 35 & 173 & 268 & 208 & 42 & 32 & 32 & 32 & 127 \\
\hline $10 \mathrm{o.m}$. & 42 & 56 & 177 & 213 & 126 & 45 & 42 & 62 & 281 \\
\hline 12 noon & 45 & 45 & 49 & 120 & 167 & 120 & 49 & 45 & 314 \\
\hline 2 p.e. & 42 & 42 & 42 & 45 & 126 & 213 & 177 & 56 & 281 \\
\hline 4 p.m. & 35 & 32 & 32 & 32 & 52 & 208 & 268 & 173 & 127 \\
\hline 6 p.m. & 57 & 17 & 17 & 17 & 17 & 105 & 211 & 192 & 64 \\
\hline 8 p.m. & 0 & 0 & 0 & 0 & 0 & 0 & 0 & 0 & 0 \\
\hline
\end{tabular}

Maximum accessible outside surface temperature of the cask shall be less than $85^{\circ} \mathrm{C}\left(185^{\circ} \mathrm{F}\right)$ in $100^{\circ} \mathrm{F}$ air temperature and in the shade.

- Reduced External Pressure. An external pressure of $24.5 \mathrm{kPa}$ (3.5 psi) absolute.

- Increased External Pressure. An external pressure of $140 \mathrm{kPa}$ (20 psi) absolute.

- Maximum Internal Pressure. An internal working pressure of 1,033 $\mathrm{kPa}(150 \mathrm{psig})$ unless otherwise specified. 
- Vibration. Vibration normally incident to transport. The package shall be evaluated per ANSI N14.23 to demonstrate containment when exposed to normal vibration due to the transfer from the $100 \mathrm{~K}$ West and East Basins to the CVD Facility and from the CVD Facility to the CSB in the 200 East Area by the selected transport vehicle. Tiedowns and hold-down bolts shall also be evaluated for this scenario.

- Water Spray. The package shall be evaluated to demonstrate containment through a water spray that simulates exposure to rainfall of approximately $5 \mathrm{~cm}$ (2 in.) per hour for at least one hour.

- Penetration. Impact of the hemispherical end of a vertical steel cylinder of 3.2-cm (1.25-in.) diameter and 6-kg (13-1b) mass, dropped from a height of $1 \mathrm{~m}(40 \mathrm{in.})$ onto the exposed surface of the package that is expected to be most vulnerable to puncture. The long axis of the cylinder must be perpendicular to the package surface.

- Package Remains on Trailer. The package shall be evaluated to demonstrate that the package is not separated from the trailer when subjected to the conditions described in Section 4.4 .

5.1.1.1 Normal Conditions of Transfer From $K$ Basins to CVD Facility. The normal conditions of transfer that are unique for the transfer of the MCO cask from the $K$ Basins to the CVD Facility are listed below. All conditions listed previously in Section 5.1.1 apply to this transfer, as well as the following.

Flat-Bottom Drop. The package shall be evaluated to demonstrate containment subsequent to a hard set-down defined by a drop flat onto the bottom of the package that causes a $5 \mathrm{~g}$ impact to the package.

5.1.1.2 Normal Conditions of Transfer From CVD Facility to CSB. The normal conditions of transfer that are unique for transfer of the MCO cask from the CVD Facility to the CSB are listed below. All conditions listed previously in Section 5.1.1 apply to this transfer, as well as the following.

Free Drop. The package shall be evaluated to demonstrate containment subsequent to a $0.3-\mathrm{m}(1-\mathrm{ft})$ free drop onto an 8-in.-thick concrete surface with a concrete strength of 4,000 psi, Grade 60, No. 7 rebar spaced 12. in. apart with 2-in. cover, each way, each face, and a Soil Modulus of Elasticity of 28,000 psi. The package shall impact in an orientation expected to cause maximum damage. Secondary impact of the package (slapdown) does not have to be examined for this drop. During the free drop, the MCO shall not be exposed to greater than $100 \mathrm{~g}$ 's and shall maintain containment.

5.1.1.3 Containment. The cask shall be designed, constructed, and prepared for shipment so that when subjected to normal conditions, the containment boundary shall remain leaktight in accordance with the ANSI 14.5 definition of "leaktight." If the package design incorporates a venting feature, the leakage rate evaluation shall be made with the vent(s) sealed. 
For conditions normally incident to transfer, the packaging shall be evaluated by analysis to meet the containment criteria listed above.

5.1.1.4 Shielding. The maximum surface dose on the accessible surface of the package shall not exceed $200 \mathrm{mrem} / \mathrm{h}$. The cask shall be designed so the maximum surface dose on the accessible surface of the package does not exceed $100 \mathrm{mrem} / \mathrm{h}$. The dose rate $2 \mathrm{~m}(6.5 \mathrm{ft})$ from the surface shall be 1 imited to $10 \mathrm{mrem} / \mathrm{h}$. The dose in any normally occupied space in the transfer vehicle shall be 1 imited to $2 \mathrm{mrem} / \mathrm{h}$ or less.

5.1.1.5 Criticality. The package design shall ensure that the package will meet the following criteria.

- The contents shall remain subcritical ( $k_{\text {eff }}$ less than 0.95 , where 0.95 is the mean value plus two times the one standard deviation value [two standard deviations] with bias applied) for the packages during normal conditions of transfer, as described in Section 5.1.1, also assuming the following.

- The most reactive credible configuration is consistent with the chemical and physical form of the allowed packaged material.

- Moderation by water to the most reactive credible extent

- Close reflection of the containment system by water on all sides or such greater reflection of the containment system as may additionally be provided by the surrounding material of the packaging.

- The package design shall aiso ensure that three packages stacked together in any arrangement with close full reflection on all sides of the stack by water will remain subcritical (as defined above).

\subsubsection{Accident Conditions}

The report on equivalent safety (WHC 1994) provides a description of how a highly controlled transportation environment, such as that available on the Hanford Reservation, can contribute to the safety of a packaging system.

Based on the preliminary risk evaluation (Green 1996), the following worst-case accidents meet the equivalent safety-based design criteria. For purposes of onsite package evaluation, these events are assumed to occur nonsequentially. For design evaluation, these accidents shall be evaluated at an ambient temperature between $-32^{\circ} \mathrm{C}\left(-27^{\circ} \mathrm{F}\right)$ and $47^{\circ} \mathrm{C}\left(115^{\circ} \mathrm{F}\right)$, whichever was more severe for the individual incident. Additionally, the packaging system will be evaluated carrying the worst-case payload, as described in Section 2.0 .

This section lists accident conditions for transfer of the package from the $K$ Basins to the CVD Facility and from the CVD Facility to the CSB.

Accident conditions unique to the transfer of the package from the $K$ Basins to 
the CVD Facility are identified in Section 5.1.2.1, while conditions unique to the transfer of the package from the CVD Facility to the CSB are identified in Section 5.1.2.2.

Puncture. The worst-case credible puncture incident is equivalent to a free drop of the packaging through a distance of $1 \mathrm{~m}(40 \mathrm{in}$.$) in a$ position expected to cause the maximum damage, onto the upper end of a solid, vertical, cylindrical, mild-steel bar mounted on an essentially unyielding, horizontal surface. The bar must be $15 \mathrm{~cm}(6 \mathrm{in}$.) in

diameter, with the top horizontal and its edge rounded to a radius of not more than $6 \mathrm{~mm}$ ( $0.25 \mathrm{in.})$ and of a length to cause maximum damage to the package, but not less than $20 \mathrm{~cm}$ ( 8 in.) long. Acceptance to this requirement is that there is no loss of shielding to the extent shown below in Section 5.1.2.2.

5.1.2.1 Accident Conditions for Transfer From $K$ Basins to CVD Facility. The accident conditions that are unique for the transfer of the MCO cask from the $K$ Basins to the CVD Facility are listed below. All conditions listed previously in Section 5.1.2 also apply to this transfer.

- Impact. The worst-case credible impact for the packaging system may be simulated by a free drop of $21 \mathrm{ft}$ onto an 8-in.-thick concrete surface with a concrete strength of 4,000 psi, Grade 60 , No. 7 rebar spaced 12 in. apart with 2-in. cover, each way, each face, and a Soil Modulus of Elasticity of 28,000 psi. The package shall impact in an orientation expected to cause maximum damage.

- Thermal. The maximum fire that the packaging system can be exposed to is a 15 minute, $800^{\circ} \mathrm{C}\left(1,475^{\circ} \mathrm{F}\right)$ engulfing fire that has an emissivity coefficient of 0.9 . The surface absorptivity of the package shall be the greater of the anticipated absorptivity or 0.8 . The preliminary risk evaluation (Green 1996) determined that evaluation of this thermal accident against the criteria of Section 5.1.2.3 would satisfy onsite transportation criteria. The SARP will also evaluate other less severe thermal accidents to ensure the criteria of Section 5.1.2.3 are satisfied.

Active cooling of the package following the 15-minute fire can be assumed. If assumed, the active cooling shall consist of quenching the outer package surfaces using water spray from a fire hose rated at $125 \mathrm{gal} / \mathrm{min}$. Flow at this maximum flow rate shall be assumed to occur for a maximum of 45 minutes. If needed, additional quenching water flow can be assumed for an additional period of 100 minutes at a maximum flow rate of $50 \mathrm{gal} / \mathrm{min}$. Assume a water temperature of $29^{\circ} \mathrm{C}\left(85^{\circ} \mathrm{F}\right)$ for this procedure.

5.1.2.2 Accident Conditions for Transfer From CVD Facility to CSB. The following are accident conditions that are unique for transfer of the MCO cask from the CVD Facility to the CSB. All conditions listed previously in Section 5.1.2 also apply to this transfer. 
- Impact. The worst-case credible impact for the packaging system may be simulated by a free drop of $30 \mathrm{ft}$ onto an 8-in.-thick concrete surface with a concrete strength of $4,000 \mathrm{psi}$, Grade 60 , No. 7 rebar spaced 12 in. apart with 2 -in. cover, each way, each face, and a Soll Modulus of Elasticity of 28,000 psi. The package shall impact in an orientation expected to cause maximum damage. The MCO shall not be exposed to greater than $100 \mathrm{~g}$ 's during this drop scenario.

- Thermal. The maximum fire that the packaging system can be exposed to during the transfer from the CVD Facility to the CSB is a 30 minute, $800^{\circ} \mathrm{C}\left(1,475^{\circ} \mathrm{F}\right)$ engulfing fire that has an emissivity coefficient of 0.9 . The surface absorptivity of the package shall be the greater of the anticipated absorptivity or 0.8 . The package can be assumed to be cooled after the fire. Any active cooling system for the packaging shall be assumed to be inoperative during the fire. The preliminary risk evaluation (Green 1996) determined that evaluation of this thermal accident against the criteria of Section 5.1.2.3 would satisfy onsite transportation criteria. The SARP will also evaluate other less severe thermal accidents to ensure the criteria of Section 5.1.2.3 are satisfied.

Active cooling of the package following the 30-minute fire can be assumed. If assumed, the active cooling shall consist of quenching the outer package surfaces using water spray from a fire hose rated at $125 \mathrm{gal} / \mathrm{min}$. Flow at this maximum flow rate shall be assumed to occur for a minimum of 45 minutes. If needed, additional quenching water flow can be assumed for an additional period of 100 minutes at a maximum flow rate of $50 \mathrm{gal} / \mathrm{min}$. Assume a water temperature of $29^{\circ} \mathrm{C}\left(85^{\circ} \mathrm{F}\right)$ for this procedure.

5.1.2.3 Containment. During and subsequent to all credible or probable accident events, as described in Section 5.1.2, the packaging system shall provide the confinement function and meet the dose consequence criteria of the Report on Equivalent Safety for Transportation of Radioactive Materials (WHC 1994) for any release of radioactive material. A radiological risk evaluation will support the credible accident scenarios.

5.1.2.4 Shielding. Subsequent to all credible or probable accident events, as described in Section 5.1 .2 , the dose $1 \mathrm{~m}(3.3 \mathrm{ft})$ from the surface of the packaging system shall not exceed 1 rem $/ \mathrm{h}$.

5.1.2.5 Criticality. Subsequent to all credible or probable accident events, as described in Section 5.1.2, the packaging system shall be evaluated for one package to meet the following criteria.

The contents shall remain subcritical ( $k_{\text {eff }}$ less than 0.95 , as defined in Section 5.1.1.5) for the packaging system during and subsequent to an accident condition, also assuming the following. 
- The fissile material is in the most reactive credible configuration consistent with the chemical form and damaged condition of the package and payload.

- There is optimum interspersed aqueous moderation.

- There is clustering of packages and close reflection of the package array by water on all sides.

5.1.2.6 Risk Evaluation. The preliminary risk evaluation was performed to establish the equivalent safety-based design criteria. This assessment was used to develop the design criteria stated in 5.1.2. A radiological risk evaluation will be developed for the SARP and will evaluate credible accident scenarios to meet the onsite transportation safety criteria (Mercado 1994).

\subsection{ALARA}

The design features of the packages shall be consistent with the requirements of WHC Occupational ALARA Progran (WHC 1995), for the Hanford Site. Exposure of personnel to radiological and other hazardous materials associated with the loading, closure, tiedown, transfer, and off-loading of the package shall be minimized. Cost benefit analyses should be performed, as needed, to determine the best balance between exposure and economical design.

The contamination limits, as directed by 49 CFR 173.443 (see Table 5), will be met prior to transport of the packaging.

\section{$5.3 Q A$}

The QA program requirements for activities such as design, procurement, fabrication, inspection, testing, component handling, and documentation of the fuel casks and their components shall be equivalent to the applicable portions of 10 CFR 71, Subpart H, and WHC-CM-4-2, Quality Assurance Manual.

To establish a QA plan for the packagings, a graded approach shall be used to define the safety $c l$ ass of both the system and individual components of the packaging system. The application of the safety class system is fully documented in WHC-CM-4-46, Nonreactor Facillity Safety Analysis Manual. The criteria for transportation safety $c l a s s$ evaluations are documented in WHC-SD-TP-RPT-001 (WHC 1994). QA requirements shall be developed for the procurement, fabrication, and inspection of the package based on the assigned transportation safety class of the package.

\subsubsection{System Safety Class}

The transportation safety class of the packages with a worst-case payload was determined by a dose consequence study, documented in Appendix $A$. This study assumed a total fallure of the canister packaging system and the release of all of its contents to the environment at the worst possible location on the transportation route. For the shipment of the irradiated fuel, the worstcase release location is within the $100 \mathrm{~K}$ Area, just outside the Basins. 
The transportation safety class dose consequence study (Appendix A), performed for 270 elements in the rerack basket scenario, indicates that the maximum inhalation dose to an onsite receptor is 240,000 rem effective dose equivalent (EDE), and the maximum inhalation dose to an offsite receptor is 120 rem EDE. Therefore, for 270 reracked elements, the packaging constitutes a Safety Class 1 system per WHC-SD-TP-RPT-001 (WHC 1994) and WHC-CM-4-46.

\subsection{DESIGN FORMAT}

Development of the design drawings, design changes, and other design documentation, if required, shall be in accordance with WHC-CM-6-1, Standard Engineering Practices.

\subsection{ENVIRONMENTAL COMPLIANCE}

Actions and conditions for the protection of the environment during transport of the packaging shall comply with the requirements of WHC-CM-7-5, Environmental Compliance.

\subsection{MAINTENANCE}

Maintenance, as required and specified in the SARP, shall be performed on the packaging to ensure packaging integrity is maintained. Ease and minimization of maintenance shall be considered in the design of the packaging. Vendor-supplied spare parts and maintenance data, if applicable, shall be provided for equipment specified in the design. Special tools required to operate the packaging system and/or replace/repair components shall also be provided as part of the project.

\subsection{SARP}

A SARP will be prepared based upon the above design criteria that will provide the safety analysis necessary to demonstrate that the packaging meets or exceeds all Hanford Site packaging safety acceptance criteria. Operational (loading and off-loading), maintenance, acceptance, and QA criteria will be included in the SARP, ensuring that operation, transport, and storage of the package meets the requirements of this PDC. The onsite SARP table of contents is found in Appendix B.

\subsection{REFERENCES}

10 CFR 71, 1996, "Packaging and Transportation of Radioactive Material, " Code of Federal Regulations, as amended.

29 CFR 1910, 1996, "Occupational Safety and Health Standards," Code of Federal Regulations, as amended. 
49 CFR 173, 1996, "Shippers--General Requirements for Shipments and Packagings," Code of Federal Regulations, as amended.

ASME, 1992, ASNE Boiler \& Pressure Vessel Code, American Society of Mechanical Engineers, New York, New York.

Fadeff, J. G., 1992, Environmental Conditions for On-Site Hazardous Materials Packages, WHC-SD-TP-RPT-004, Rev. 0, Westinghouse Hanford Company, Richland, Washington.

Fischer, L. E., and W. Lai, 1985, Fabrication Criteria for Shipping Containers, NUREG/CR-3854, (under Lawrence Livermore National Laboratory contract to the U.S. Nuclear Regulatory Commission), U.S. Nuclear Regulatory Commission, Washington, D.C.

Green, J. R., 1996, Radiological Risk Evaluation for Risk-Based Design Criteria of the Nultiple Container Overpack Packaging, WHC-SD-TP-RPT-022, Rev. 1, Westinghouse Hanford Company, Richland, Washington.

H\&R, 1995, Recommended Onsite Transportation Risk Management Methodology, 522-1, H\&R Technical Associates, Inc., Oak Ridge, Tennessee.

HSRCM-1, 1994, Hanford Site Radiological Control Manual, Pacific Northwest Laboratory, Richland, Washington.

IAEA, 1990, Advisory Material for the IAEA Regulations for the Safe Transport of Radioactive Material, Safety Series 37, 3rd Edition, International Atomic Energy Agency, Vienna, Austria.

Mercado, J. E., 1994, Report on Equivalent Safety for Transportation and Packaging of Radioactive Materials, WHC-SD-TP-RPT-001, Rev. 0 , Westinghouse Hanford Company, Richland, Washington.

NRC, 1991a, Fracture Toughness Criteria of Base Material for Ferritic Steel Shipping Cask Containment Vessels with a Maximum Wall Thickness of 4 Inches, Regulatory Guide 7.11, U.S. Nuclear Regulatory Commission, Washington, D.C.

NRC, 1991b, Fracture Toughness Criteria of Base Naterial for Ferritic Steel Shipping Cask Containment Vessels with a Wall Thickness Greater Than 4 Inches, But Not Exceeding 12 Inches, Regulatory Guide 7.12, U.S. Nuclear Regulatory Commission, Washington, D.C.

NRC, 1984, NRC IE Information Notice 84-72, September 10, U.S. Nuclear Regulatory Commission, Washington, D.C.

Pajunen, 1996, Bounding Particulate Contents of a Nulti-Canister Overpack, WHC-SD-SNF-TI-023, Rev. 1, Westinghouse Hanford Company, Richland, Washington.

Schwarz, R. A., 1995, Neutron and Photon Baseline Source Terms for K-Basin Shielding, Internal Memo 8M730-LLC-95-011R1, Westinghouse Hanford Company, Richl and, Washington. 
WHC-CM-1-10, Safety Manual, Westinghouse Hanford Company, Richland, Washington.

WHC-CM-2-14, Hazardous Material Packaging and Shipping, Westinghouse Hanford Company, Richland, Washington.

WHC-CM-4-2, Quality Assurance Manual, Westinghouse Hanford Company, Richland, Washington.

WHC-CM-4-46, Safety Analysis Manual, Westinghouse Hanford Company, Richland, Washington.

WHC-CM-6-1, Standard Engineering Practices, Westinghouse Hanford Company, Richl and, Washington.

WHC-CM-7-5, Environmental Compliance, Westinghouse Hanford Company, Richland, Washington.

WHC, 1995, WHC Occupational ALARA Program, WHC-IP-1043, Rev. 0, Westinghouse Hanford Company, Richland, Washington.

WHC, 1994, Report on Equivalent Safety for Transportation of Radioactive Nateria7s, WHC-SD-TP-RPT-001, Rev. 0, Westinghouse Hanford Company, Richl and, Washington. 
Rev. 3

This page intentionally left blank. 


\section{APPENDIX A \\ SAFETY CLASSIFICATION FOR THE $K$ BASIN CASK}

C. H. Huang

December 5, 1995

\subsection{INTRODUCTION}

Approximately 2,100 metric tons of unprocessed, irradiated nuclear fuel presently are stored in the $K$ Basins. To clean up this nuclear spent fuel in the $K$ Basins, the fuel must be transported from the $100 \mathrm{~K}$ Basin Area to a Canister Storage Building (CSB) in the 200 East area. The shipping transport operation involves loading the irradiated fuel into the Multiple Canister overpack (MCO) cask assembly at the $100 \mathrm{~K}$ Basin Area. The cask may be transported by either truck or train.

A transportation accident resulting in a fire is postulated.

In this document, the onsite and offsite doses were calculated to determine the safety classification for the system (the $K$ Basin cask) or components associated with the cask transport operations.

\subsection{PURPOSE}

The purpose of this document is to provide the safety classification for a packaging and transportation system (the $K$ Basin cask) to transport spent nuclear fuel within the boundary of the Hanford Site.

\subsection{SCOPE OF AMALYSIS}

This safety class analysis addresses the transportation of the $K$ Basin cask. In this analysis, only a bounding accident scenario will be analyzed.

\subsection{SOURCE TERM}

\section{customer.}

The worst-case source term for $N$ Reactor fuel was specified by the

In addition to the $N$ fuel elements, a portion of the $N$ Reactor fuel in both basins to be transported in the packaging system also is in the form of small fuel particles and radioactive corrosion products. 
The fuel that is being stored in the $K$ Basins is stored in double barrelled canisters that contain up to $14 \mathrm{~N}$ Reactor fuel assemblies. The fuel is removed from these canisters and placed in baskets inside of the MCO. A maximum of 270 assemblies will be placed in these baskets.

\subsection{RADIOACTIVE INVENTORY}

The inventory in the baskets is contained within the MCO. The MCO acts as the primary container vessel. Table 1 shows the anticipated activity per unit mass, per assembly, and per cask. The cask contains a total of 270 assemblies.

Table 1. Worst-Case Source Term for $N$ Reactor Fuel. (provided by the customer)

\begin{tabular}{|c|c|c|c|c|c|c|c|}
\hline I sotope & $\begin{array}{l}\text { Curien } \\
\text { per ATU }\end{array}$ & $\begin{array}{l}\text { Curies per } \\
\text { single } \\
\text { ossenbly }\end{array}$ & $\begin{array}{l}\text { Curies per } \\
\text { Mco--270 } \\
\text { escembl fes }\end{array}$ & Isotope & $\begin{array}{l}\text { Curies } \\
\text { per MTU }\end{array}$ & $\begin{array}{l}\text { Curies per } \\
\text { single } \\
\text { acsenbly }\end{array}$ & $\begin{array}{c}\text { Curies per } \\
\text { nco--270 } \\
\text { essemblies }\end{array}$ \\
\hline $3_{H}$ & 38.8 & 0.91 & 246 & ${ }^{144} \mathrm{Ce}$ & 2.5 & 0.06 & 16 \\
\hline${ }^{55} \mathrm{Fe}$ & 6.8 & 0.16 & 43 & ${ }^{144} \mathrm{Pr}$ & 2.5 & 0.06 & 16 \\
\hline${ }^{60} \mathrm{Co}$ & 6.5 & 0.15 & 41 & ${ }^{147} \overline{P m}_{\mathrm{Pm}}$ & 1084.4 & 25.5 & 6875 \\
\hline${ }^{85} \mathrm{Kr}$ & 611.5 & 14.36 & 3,877 & $151_{\mathrm{sm}}$ & 102.7 & 2.41 & 651 \\
\hline${ }^{90} \mathrm{sr}$ & $7,893.6$ & 185.35 & 50,045 & ${ }^{154} \mathrm{Eu}$ & 215.1 & 5.05 & 1364 \\
\hline $90 y$ & $7,893.6$ & 185.35 & 50,045 & ${ }^{155} \mathrm{EU}$ & 16.4 & 0.39 & 104 \\
\hline${ }^{106}{ }_{R U}$ & 11.5 & 0.27 & 73 & ${ }^{238} 8_{\mathrm{Pu}}$ & 147.3 & 3.46 & 934 \\
\hline $106_{\mathrm{Rh}}$ & 11.5 & 0.27 & 73 & $239_{\mathrm{Pu}}$ & 152.1 & 3.57 & 964 \\
\hline $125 \mathrm{sb}$ & 99.1 & 2.33 & 628 & ${ }^{240} \mathrm{Pu}$ & 115.0 & 2.70 & 729 \\
\hline${ }^{125} \mathrm{~m}_{\mathrm{Te}}$ & 24.1 & 0.57 & 153 & $241_{\mathrm{Pu}}$ & $9,140.9$ & 214.64 & 57,953 \\
\hline${ }^{134} \mathrm{cs}$ & 115.0 & 2.70 & 729 & $261_{\mathrm{Am}}$ & 269.7 & 6.33 & 1710 \\
\hline${ }^{137} \mathrm{Cs}_{\mathrm{s}}$ & $10,735.4$ & 252.08 & 68,062 & $266 \mathrm{~cm}$ & 3.9 & 0.09 & 25 \\
\hline $137 \mathrm{Bg}_{\mathrm{Ba}}$ & $10,162.8$ & 238.64 & 64,432 & & & & \\
\hline
\end{tabular}

MCO = Multiple Cenister Overpeck.

MTU = Metric tons of uraniun.

\subsection{ACCIDENT SCENARIOS/INITIATING EVENTS}

The bounding condition considered for the accident scenario is a fire accident.

The possible cause of a fire accident is that the truck fuel could catch fire due to traffic accidents.

In the accident postulated, all of the fuel in the MCO is assumed to be exposed and surrounded by fire. 


\subsection{RELEASE FRACTION}

An airborne release fraction (ARF) of $5.0 \times 10^{-3}$ (DOE 1994, pp. 4-37) is used to calculate the doses at the onsite and offsite receptor locations for the fire scenario. This release fraction was taken from DOE (1994) and is associated with oxidation of uranium. The $5 \times 10^{-3}$ was selected because it is the most conservative value. This release fraction is applied to all radionuclides present, except for cesium, ruthenium, and tellurium, which are considered semivolatile. The release fraction for ruthenium and tellurium was taken to be $1 \times 10^{-2}$ (DOE 1992, p. A-9). The release fraction for cesium was taken to be 0.09 (DOE 1994). The release fraction for krypton and tritium was taken to be 1.0 (DOE 1992, p. A-9).

The quantity of airborne radioactive material released from the fire is therefore equal to the activity of each radionuclide listed in Table 1 times the release fraction.

The worst-case source term for $N$ Reactor fuel, adjusting for the airborne release fraction, is given in Table 2 . 
Table 2. Worst-Case Source Term for N Reactor Fuel.

\begin{tabular}{|c|c|c|c|}
\hline 1sotope & Ci/cask & Isotope & Ci/Cans \\
\hline $3_{H}$ & $2.5 E+2$ & ${ }^{146} \mathrm{ce}$ & Q.0E-2 \\
\hline${ }^{55} \mathrm{Fe}$ & 2.2E-1 & $144 \mathrm{Pr}$ & 8.0E-2 \\
\hline${ }^{60} \mathrm{Co}$ & 5.1 & $167_{\mathrm{Pm}}$ & 7. $\pi E+1$ \\
\hline $85_{K r}$ & $3.9 E+3$ & $151_{\mathrm{sin}}$ & 3.3 \\
\hline${ }^{90} \mathrm{sr}$ & $2.5 E+2$ & ${ }^{154} \mathrm{EU}$ & 6.1 \\
\hline $90_{Y}$ & $2.5 E+2$ & $155_{\mathrm{Eu}}$ & 1.1 \\
\hline $106_{\mathrm{Ru}}$ & $7.3 \mathrm{E}-1$ & $238_{\mathrm{Pu}}$ & 4.7 \\
\hline${ }^{106_{\text {Rh }}}$ & $3 . \pi-1$ & $239_{\mathrm{Pu}}$ & 4.8 \\
\hline $125_{\mathrm{sb}}$ & 3.1 & ${ }^{240} \mathrm{Pu}$ & 3.6 \\
\hline $125 \mathrm{me}$ & 1.5 & $241_{\mathrm{PU}}$ & $2.9 E+2$ \\
\hline${ }^{134} \mathrm{cs}$ & $6.6 E+1$ & $261 \mathrm{Am}$ & 8.7 \\
\hline${ }^{137} \mathrm{Cs}$ & $6.1 E+3$ & ${ }^{244} \mathrm{~cm}$ & 1.3 \\
\hline $1377_{\mathrm{Ba}}$ & 3. $2 E+2$ & & \\
\hline
\end{tabular}

\subsection{METHODOLOGIES AND ASSUMPTIONS}

Acute maximum individual ground-level release doses for the onsite and offsite receptors were calculated using the computer code GENII version 1.485 (Napier et al. 1988).

\subsection{CODE DOCUMENTATION}

- GENII version $1.485(12 / 3 / 90)$

- GENII Default Parameter Values (28-Mar-90 RAP)

- Radionuclide Master Library (7/23/93 PDR)

- PNL Food Transfer Factor Library (7/19/93)

- External Dose Factor Library (8-May-90-RAP)

- Internal Dose Increments, PNL Solubilities (7/23/93 PDR)

- Joint Frequency Data: 100 Area, $10 \mathrm{~m}$, Pasqui11 A-G (19831991 Average). The worst dose consequences would occur in the 100 Area.

GENII input files are attached in Appendix $A$. 


\subsection{RESULTS}

The safety class for the $K$ Basin cask transporting $N$ Reactor fuel assemblies was determined in accordance with the guidance provided in WHC-CM-4-46, 9.0, Rev. 0, "Assigning Safety Classes to Systems, Components and Structures." In the case of radioactive materials, the fallure of a system or component that could result in an offsite public exposure in excess of 500 mrem effective dose equivalent is classifled as Safety Class 1. The guidance for making a safety class determination for a facility or a system indicates that the safety classification is based upon the determination of consequences of potential accidents without the mitigation provided by engineered or administrative barriers. In addition, the entire inventories of hazardous materials allowed in the facility or the system are assumed to be present.

Atmospheric dispersion factor, $X / Q$ s, for the onsite and offsite receptors were taken from Savino (1995). The onsite receptor is located $100 \mathrm{~m}$ from the source; the offsite receptor is 11,730 m west of the $K$ Basins (current site boundary). For the proposed site boundary (see foptnotes in Table 3 ), the maximum offsite receptor $X / Q$ value is $1.54 E-02 \mathrm{~s} / \mathrm{m}^{3}$, which is associated with a receptor at $150 \mathrm{~m}$ in the northwest direction from the $100 \mathrm{~K}$ Area. The calculated values of $X / Q$ are given in Table 3 for the onsite and offsite receptors.

Table 3. The Values of $X / Q$ for the Onsite, Near Riverbank, and offsite Receptors

in the Worst Sector.

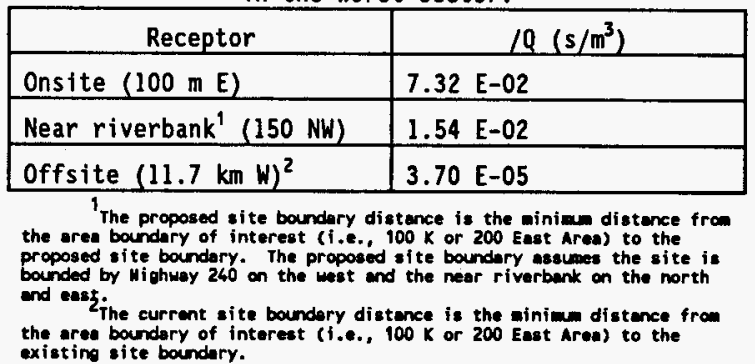

The values of $X / Q$, as shown in Table 3 , are used as input data into the GENII code for dose calculations. The calculated doses for the onsite and offsite receptors are given in Table 4. 
Table 4. The Calculated Doses for the Onsite, Near Riverbank, and Offsite Receptors.

\begin{tabular}{|l|l|}
\hline \multicolumn{1}{|c|}{ Receptor } & \multicolumn{1}{|c|}{$\begin{array}{c}\text { Effective dose } \\
\text { equivalent (rem) }\end{array}$} \\
\hline Onsite $(100 \mathrm{~m} \mathrm{E})$ & $2.4 \mathrm{E}+05$ \\
\hline Near riverbank ${ }^{1}(150 \mathrm{~m} \mathrm{NW})$ & $4.9 \mathrm{E}+04$ \\
\hline Offsite $(11.7 \mathrm{~km} \mathrm{~W})^{2}$ & $1.2 \mathrm{E}+02$ \\
\hline
\end{tabular}

As shown in Table 4, the exposures to the public at a near riverbank receptor and an offsite receptor are $4.9 \times 10^{4}$ and $1.2 \times 10^{2} \mathrm{rem}$, respectively, which exceed the 500 mrem threshold limit for Safety Class 1. Therefore, the $K$ Basin cask loaded with $N$ reactor fuel is classified as Safety Class 1.

\subsection{REFERENCES}

DOE, 1992, Hazard Categorization and Accident Analysis Techniques for Compliance with DOE Order 5480.23, Nuclear Safety Analysis Reports, DOE-STD-1027-92, U.S. Department of Energy, Washington, D.C.

DOE, 1994, Airborne Release Fractions/Rates and Respirable Fractions for Nonreactor Nuclear Facilities, DOE-HDBK-3010-94, U.S. Department of Energy, Washington, D.C.

Hartmann, I., J. Nagy, and M. Jacobson, 1951, The Explosive Characteristics of $T i, Z r, T h, U$ and Their Hydrides, U.S. Bureau of Mines Report 4835.

Napier, B. A., et al., 1988, GENII - The Hanford Environmental Radiation Dosimetry Software System, PNL-6484, Pacific Northwest Laboratory, Richland, Washington.

Peacock, H. B., 1992, Pyrophoricity of Uraniun, WSRC-TR-92-106, Savannah River Laboratory, Aiken, South Carolina.

Savino, A. V., 1995, Preliwinary Dose Consequence Study for the Hanford Interarea Protective Package Overpack (HIPPO), 8M400-AVS-95-007, Draft, Westinghouse Hanford Company, Richland, Washington.

WHC-CM-4-46, Nonreactor Facility Safety Analysis Manual, Westinghouse Hanford Company, Richland, Washington. 


\section{APPENDIX A}

\section{GENII INPUT FILES}

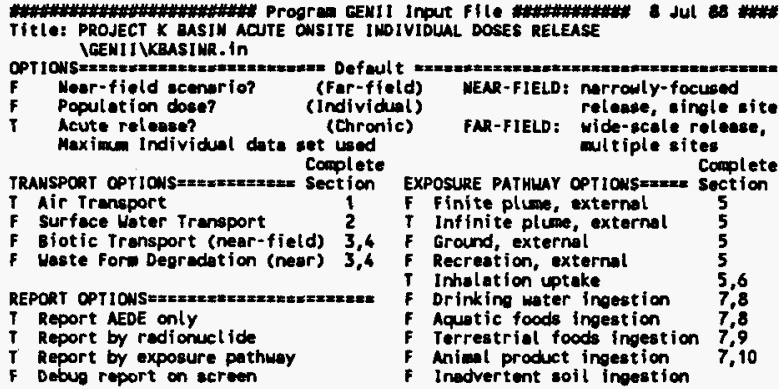

INVENTORY \#\#\#

4 Imventory input activity unite: (1-pci 2-uci 3-aci 4-Ci 5-8q)

0 Surface soil source units (1- 22 2- $33-\mathrm{kg})$

Equilibrium question goes here

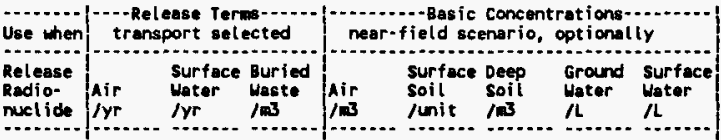

$\begin{array}{lll}3 & \\ & 2.5 E+2\end{array}$

FES5 2.2E-1

Co60 5.1

KR85 3. $9 E+3$

$\$ 280 \quad 2.5 E+2$

Y $90 \quad 2.5 E+2$

RU106 7.3E-1

SB125 3.1

TE125M 1.5

CS134 $6.6 E+1$

CS137 6.1E+3

CE144 8.0E-2

PR144 8.0E-2

PN147 7.TE+

\$151 3.3

EUt54 6.9

EU155 1.1

PU238 4.7

PU239 4.8

PU240 3.6

PU241 2.9E+2

N1241 8.7

$0.244 \quad 1.3$

.........--Derived Concentrations-..---

Use then messured velues are known

.

Release Prerres. Animel prink Aquat ic

muclide $/ \mathrm{kg} / \mathrm{kg} / \mathrm{h} \quad / \mathrm{kg}$

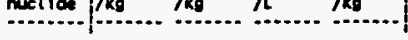


1 Intoke end ofter (yr)

50 Dose colc. ends ofter (yr)

Release ende after $(y r)$

No. of yess of air deposition prior to the intake period

No. of vears of irrigation water deposition prior to the intake period

FAR-FIELD SCENARIOS (IF POPULATION DOSE)

0 Definition option: 1-Use population orid in file POP.IN

2-Use totel entered on this IIne

\section{MEAR-FIELD SCEMARIOS \#}

Prior to the beginning of the intake period: (yr)

When wes the inventory disposed? (Peckege degredation eterte)

When was lolc? (Biotic traneport eterts)

Fraction of roote in uper soll (tep $15 \mathrm{en}$ )

irection of roots in deep soll

Menul redistribution: deep soil/eurfece soll dilution factor

source erea for external dose nodificetion factor (a2)

TRANSPOR

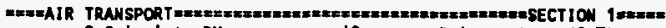
0-Colculate PN 10 . Release type (0-3)

Option: 1-Use chi/O or PN value if Stack release (T/F) 2-select MI digt dir o stock height (m) 3-Specify MI dist \& dir lo stack flow (m/sec)



MI eector index (1=\$) Effluent teap. (C)

Mi distance from release point $(m) \int_{0}$ Building $x$-section $(-2)$

Use jf dete, (T/F) etse chi/Q gridjo Building height (m)

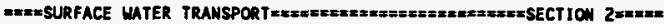
Mixing ratio model: 0-use value, 1-river, 2-lake

Mixing ratio, dimensionless

Average river flow rate for: MIXFLG=0 (m3/s), MIXFLG=1,2(E/s),

Franeit time to irrigation withdrawal location (hr)

If mixing retio model $>0$ :

Rate of effluent discharge to receiving weter body $\left(\mathrm{m}^{3} / \mathrm{s}\right)$

Longshore distance from release point to usage location (m)

Offshore distance to the water intake (a)

Average water depth in surface water body (a)

Average river width (m), MIXFLG=1 only

Depth of effluent discharge point to surface water (m), lake only


Waste form/peckage half life, (Yr)

Waste thickness, (m)

Depth of soil overburden, $m$

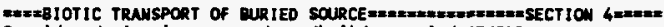
Consider during inventory decay/buildup period (T/F)?

Consider during intake period (T/F)? 1-Arid non agricultural

Pre-Intake site condition............... 2 2-Humid non agricultural

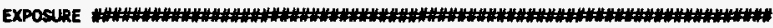

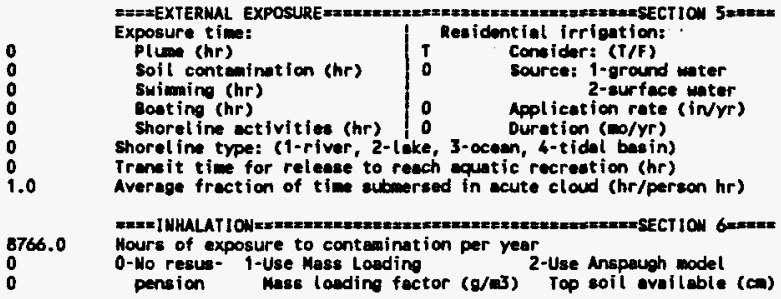




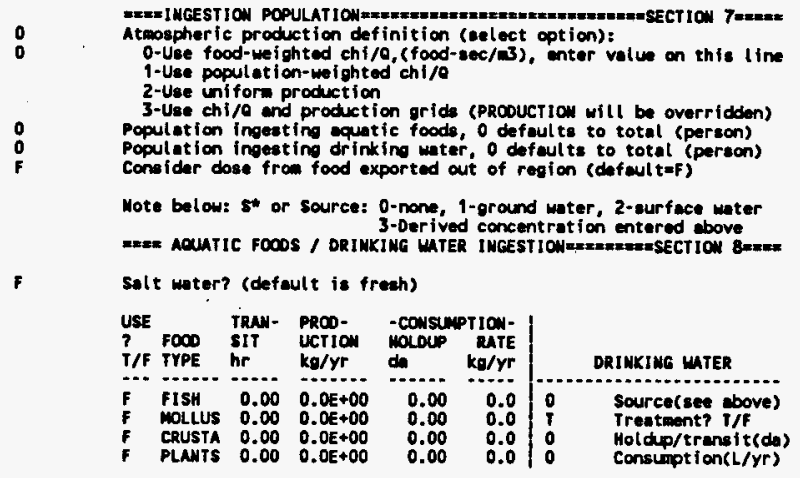

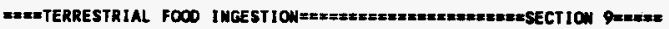

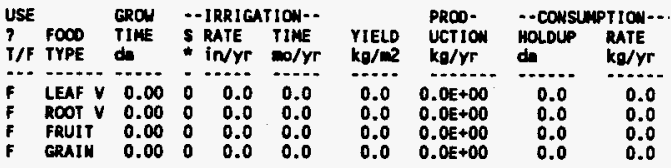

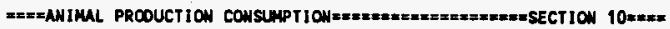

\begin{tabular}{|c|c|c|c|c|c|c|c|c|c|c|}
\hline $\begin{array}{l}\text { USE } \\
? \\
T / F\end{array}$ & $\begin{array}{l}\text { FOOD } \\
\text { TYPE }\end{array}$ & $\begin{array}{l}\text { CONSUAPTION } \\
\text { RATE HOLDUP } \\
\text { kg/Yr do }\end{array}$ & $\begin{array}{l}\text { TOTAL } \\
\text { PRCD- } \\
\text { UCTIOA } \\
\text { kg/Yr }\end{array}$ & $\begin{array}{l}\text { ORINK } \\
\text { WATER } \\
\text { CONTAN } \\
\text { FRACT. }\end{array}$ & $\begin{array}{l}\text { DIET } \\
\text { FRAC- } \\
\text { TION }\end{array}$ & $\begin{array}{l}\text { GROA } \\
\text { TIME } \\
\text { da }\end{array}$ & $\begin{array}{l}\text {-STORED } \\
\text {-IRRIGAT } \\
\text { S RATE } \\
\text { in/Yr }\end{array}$ & $\begin{array}{l}\text { FEED-- } \\
\text { TION-- } \\
\text { TINE } \\
\text { mo/yr }\end{array}$ & $\begin{array}{l}\text { YIELD } \\
k 0 /=3\end{array}$ & $\begin{array}{l}\text { STOR- } \\
\text { AGE } \\
\text { da }\end{array}$ \\
\hline $\begin{array}{l}F \\
f \\
F\end{array}$ & $\begin{array}{l}\text { BEEF } \\
\text { POULTR } \\
\text { MILK } \\
\text { EOG }\end{array}$ & $\begin{array}{l}0.0 \\
0.0 \\
0.0 \\
0.0\end{array}$ & $\begin{array}{l}0.00 \\
0.00 \\
0.00 \\
0.00\end{array}$ & $\begin{array}{l}0.00 \\
0.00 \\
0.00 \\
0.00\end{array}$ & $\begin{array}{l}0.00 \\
0.00 \\
0.00 \\
0.00\end{array}$ & $\begin{array}{l}0.0 \\
0.0 \\
0.0 \\
0.0\end{array}$ & $\begin{array}{ll}0 & \\
0 & 0.0 \\
0 & 0.0 \\
0 & 0.0 \\
0 & 0.0\end{array}$ & $\begin{array}{l}0.00 \\
0.00 \\
0.00 \\
0.00\end{array}$ & $\begin{array}{l}0.00 \\
0.00 \\
0.00 \\
0.00\end{array}$ & $\begin{array}{l}0.0 \\
0.0 \\
0.0 \\
0.0\end{array}$ \\
\hline & $\begin{array}{l}\text { BEEF } \\
\text { MILK }\end{array}$ & & & & $\begin{array}{l}0.00 \\
0.00\end{array}$ & $\begin{array}{l}0.0 \\
0.0\end{array}$ & $\begin{array}{l}0.0 \\
0.0\end{array}$ & $\begin{array}{l}0.00 \\
0.00\end{array}$ & $\begin{array}{l}0.00 \\
0.00\end{array}$ & $\begin{array}{l}0.0 \\
0.0\end{array}$ \\
\hline
\end{tabular}

17. 



TitIe: PROJECT $K$ BASIN ACUTE OFfSITE INDIVIDUAL DOSES RELESAE YCEMIIUKEASHRFR, in

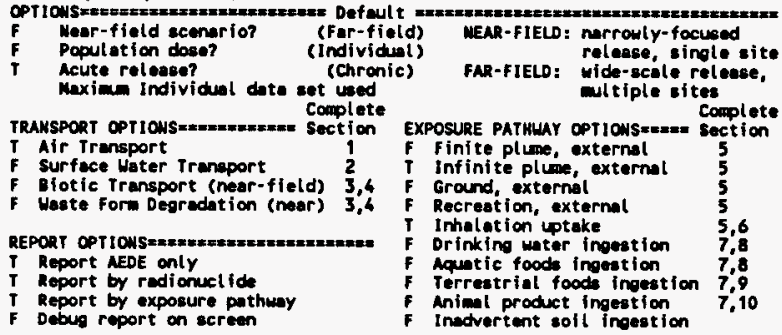

INVENTORY

4 Inventory input activity unite: (1-pci 2-uci 3-mci 4-Ci 5-Bq)

0 Surface soil source unite $(1-22-3-3-k g)$

Equilibrium question goes here

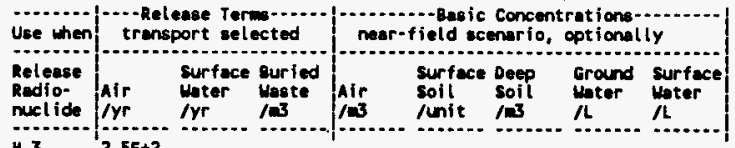

$\begin{array}{ll}1 & 2.5 E+2\end{array}$

FE5S 2.2E-1

CO60 5.1

KR85 $3.9 E+3$

SR90 2.5E+2

$Y 90 \quad 2.5 \mathrm{E}+2$

RU106 $7.3 \mathrm{E}-1$

$58125 \quad 3.1$

TE 125M 1.5

CS134 $6.6 E+1$

$\operatorname{cs} 137 \quad 6.1 E+3$

CE144 8.DE-2

PR144 8.0E-2

PM147 7.7E+1

SN151 3.3

EU154 6.1

EU155 1.1

PU238 4.7

PU239 4.8

PU240 3.6

PU241 2.9E+2

N1241 8.7

$001244 \quad 1.3$

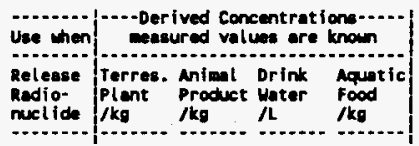

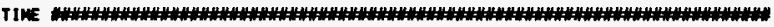

1 Intake enda ofter ( $y r$ )

50 Dose calc. ands after (yr)

0 Rel ease ende of ter (yr)

Mo. of years of air deposition prior to the intake period

Wo. of years of irrigation water deposition prior to the intake period 
FAR-FIELO SCEMARIOS (IF POPULATION DOSE)

- Definition option: 1-Use population grid in file POP.IM

2-Use total entered on this IIne

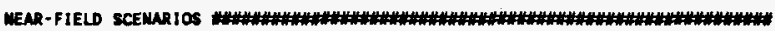

Priar to the boginning of the intake paried: (yr)

then was the inventory disposed? (Puckage degradation starta)

When wes loIC? (Bjotic trensport starts)

Frection of roots in uper coil (top $15 \mathrm{~cm}$ )

Fraction of roots in depep soll

Manual redietribution: deep soil/surface soil dilution factor

source area for external dose adification fector (m)

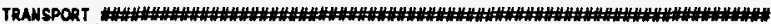


O-Calculate PN 10 Release type (0-3)

option: i-Use chi/o or PH velue ff stack release (T/F) 2-select MI dist 2 dir fo stack height (B) 3-specify MI dist 2 dir 0 stack flow (Bj/sec)

1.545-2 Chi/Q or PN value

Chila or PI value

stack rediu (a)

Ml distance from relesese point (m) 0 Building $x=\operatorname{section}(a)$

Uee jf date, (T/F) lse chi/a oridfo Building height (m)

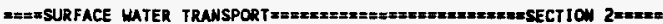
Mixing ratio nodel: 0-use value, 1-river, 2-lake

Hixing ratio, dimensionlese

Averege river flow rete for: MIXFLG=0 (m3/e), AIXFLG=1,2 (m/e).

Transft time to irrigetion withdrawal locetion (hr)

If aixing ratio model $\Rightarrow$ :

Rate of effluent discharge to receiving water body $(\mathrm{m} / \mathrm{s})$

Longshore distance from release point to usage location (m)

Offahore distance to the water intake (m)

Average water depth in curfece water body (m)

Average river width (m), MIXFLG=I only

Depth of effluent discharge point to eurface weter (m), lake only

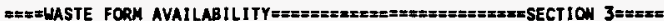
Waste form/packege half life, (yr)

Waste thickness, (a)

Depth of soil overburden,

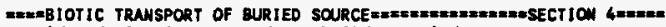
Consider during inventory decay/buildup peried (T/F)?

Consider during intake period (I/F)? | 1-Arid non agricultural

Pre-Intake site candition.............. $\begin{aligned} & \text { 2-Huid non agricultural } \\ & 3 \text {-Agricul tural }\end{aligned}$

EXPOSURE НH

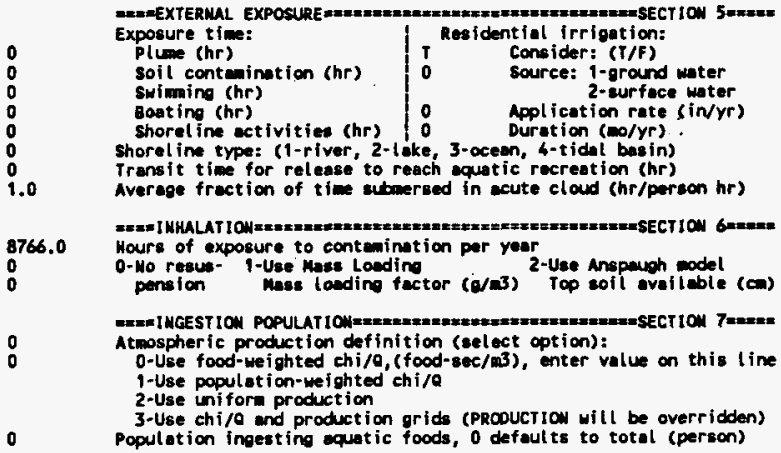


0 Population ingesting drinking water, 0 defeul ts to totel (person)

F Consider does from food exported out of region (defeult tof)

Wote balow: st or Source: 0-none, 1-ground water, 2-surface water 3-Derived concentration entered above =m= AOUATIC FOCOS / DRINKING WTER IMCESTIOH=Ex=Ex=E=SECTION \&=mE

F

Solt woter? (defoult is fresh)

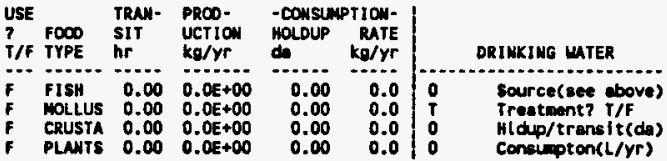

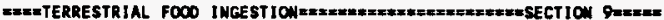

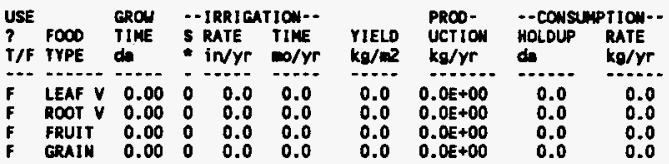

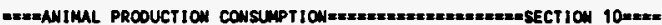

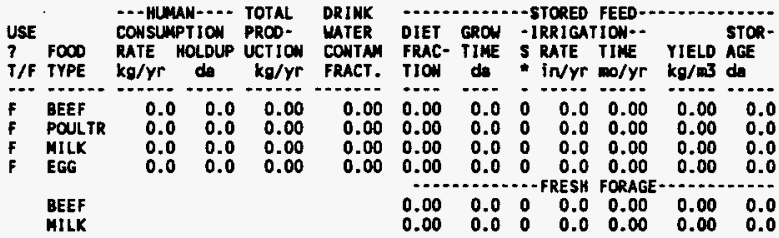




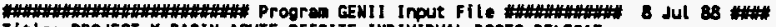
Title: PROJECT $\mathrm{K}$ BASIN ACUTE OFFSITE IWDIVIDUAL DOSES RELESAE ICENI I YKAASHFR. In

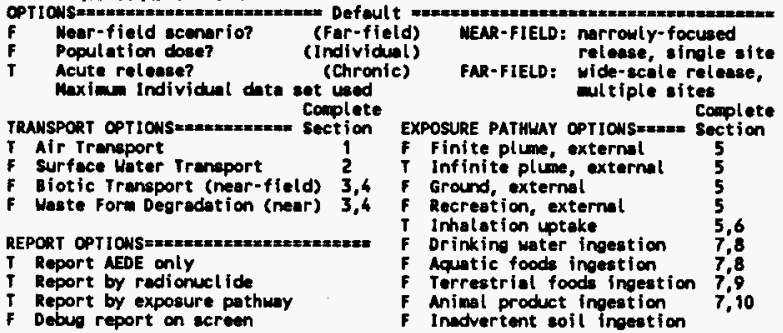

INVEMTORY

4 Inventory input ectivity unite: (1-pci 2-uci 3-uci 4-ci 5-Ba)

0 surface ooll source units (1- 2 2- $33-\mathrm{kg})$

Equilibriu question goes here



H $3 \quad 2.5 E+2$

FE55 2.2E-1

c060 5.1

KR85 $3.9 E+3$

SR90 2.5E+2

$Y 90 \quad 2.5 E+2$

RUTO6 7.3E-1

SB125 3.1

TE125M 1.5

Cs134 $6.6 E+1$

$\operatorname{cs} 1376.1 E+3$

CE144 8.0E-2

PR144 8.0E-2

PH147 7.7E+1

SM151 3.3

EU156 6.1

EU155 1.1

PU238 4.7

PU239 4.8

Pu240 3.6

PU241 $2.9 E+2$

Ni241 8.7

042661.3

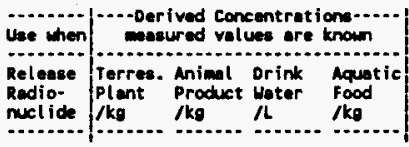

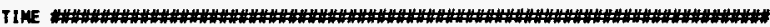

1 Intoke end ofter $(y r)$

50 Dose calc. ands after (yr)

0 Release enda after (yr)

0 No. of vears of air deposition prior to the inteke period

0 No. of vears of irrigetion weter deposition prior to the inteke period 
WHC-SD-TP-PDC-030 Rev. 3

FAM-FIELD SCEMARIOS (IF POPULATIOM DOSE)

0 Definition option: 1-Uae population orid in file POP.IN

0 2-Use total entered on this line



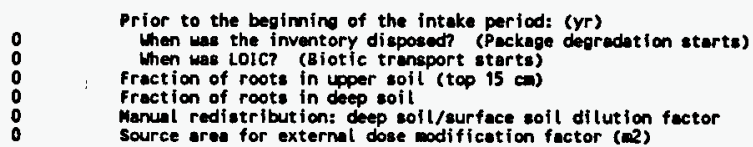

TRAMSPORT

1

3.70E-5 Ch1/0 or PH value

T.
t
T

MI diztence from relese point (m)
$T$ Use jf date, (T/F) else chi/a grid

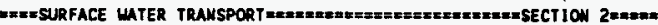
Mixing ratio model: 0 -use volus, 1-river, 2 -lake

Mixing ratio, diensionless

Average river flow rate for: MIXFLG=0 ( $B 3 / s)$, MIXFLG=1,2 (N/s),

Iransit time to irrigation withdrawal locotion (hr)

If aixing ratio model $>0$ :

Rate of effluent discharge to receiving water body $(\mathrm{m} / \mathrm{s} / \mathrm{s})$

Longshore distance from release point to ussge location (m)

Offshore distence to the wster intake (m)

Average water depth in surface water body (m)

Averoge piver width ( $(\mathbf{m})$, MIXFLGeif only

Depth of effluent discharge point to surface water $(m)$, lake only

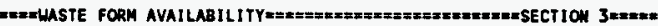
Waste formpackage half IIfe, (yr)

Woste thickness, (m)

Depth of soil overburden,

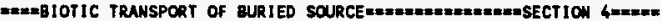
Consider during inventory decay/buildup period (T/F)?

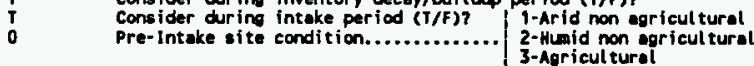



EXPOSURE

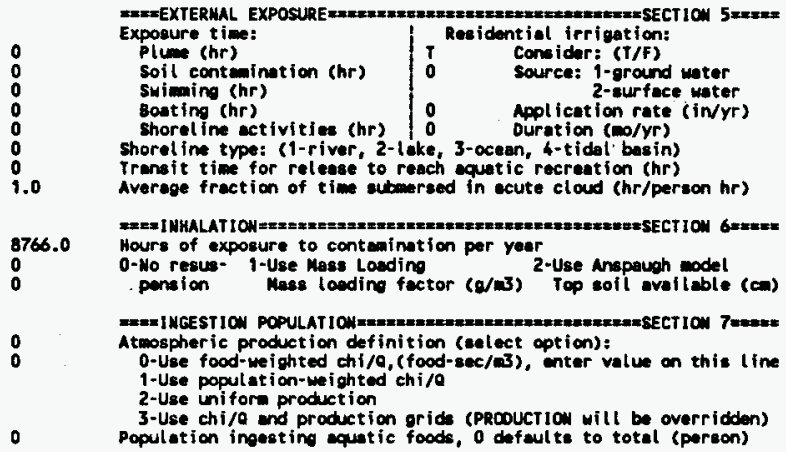


- Population inoesting drinking water, 0 defeults to totel (person) Consider dose from food exported out of region (dafeult=f)

Mote below: s* or Source: 0-none, 1-ground water, 2-surface water 3-Derived concentration entered above

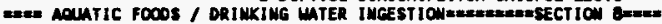
Salt water? (default is fresh)

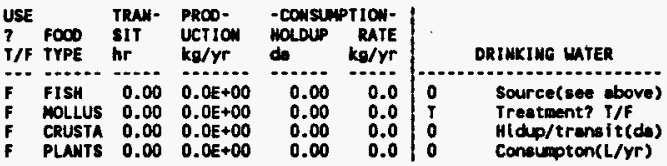

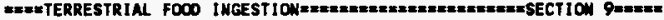

\begin{tabular}{|c|c|c|c|c|c|c|c|c|}
\hline $\begin{array}{l}\text { Use } \\
? \\
\text { T/F }\end{array}$ & $\begin{array}{l}\text { FOOD } \\
\text { TYPE }\end{array}$ & $\begin{array}{l}\text { croy } \\
\text { TINE } \\
\text { do }\end{array}$ & $\begin{array}{l}\text { - IRRIGAT } \\
\text { s RATE } \\
\text { In/YT }\end{array}$ & $\begin{array}{l}\text { TIow.. } \\
\text { TINE } \\
\text { no/yr }\end{array}$ & $\begin{array}{l}\text { YIELD } \\
\mathrm{kg} / \mathrm{m}\end{array}$ & $\begin{array}{l}\text { PROO- } \\
\text { UCTION } \\
\text { kg/Yr }\end{array}$ & $\begin{array}{l}\text {-consur } \\
\text { holpup } \\
\text { de }\end{array}$ & $\begin{array}{l}\text { PTIOW-- } \\
\text { RATE } \\
\text { kg/yr }\end{array}$ \\
\hline 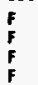 & $\begin{array}{l}\text { LEAF V } \\
\text { ROOT V } \\
\text { FRUIT } \\
\text { CRAIU }\end{array}$ & $\begin{array}{l}0.00 \\
0.00 \\
0.00 \\
0.00\end{array}$ & $\begin{array}{l}0.0 \\
0.0 \\
0.0 \\
0.0\end{array}$ & $\begin{array}{l}0.0 \\
0.0 \\
0.0 \\
0.0\end{array}$ & $\begin{array}{l}0.0 \\
0.0\end{array}$ & $\begin{array}{l}0.0 \\
0.0 \\
0.0 \\
0 .\end{array}$ & $\begin{array}{l}0.0 \\
0.0 \\
0.0 \\
0.0\end{array}$ & $\begin{array}{l}0.0 \\
0.0 \\
0.0 \\
0.0\end{array}$ \\
\hline
\end{tabular}

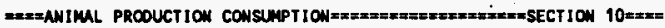

\begin{tabular}{|c|c|c|c|c|c|c|c|c|c|c|}
\hline $\begin{array}{l}\text { USE } \\
? \\
\text { T/F }\end{array}$ & $\begin{array}{l}\text { FO00 } \\
\text { TYPE }\end{array}$ & $\begin{array}{l}\text { CONSUMPTION } \\
\text { RATE HOLDUP } \\
\text { kg/Yr da }\end{array}$ & $\begin{array}{l}\text { TOTAL } \\
\text { PROD- } \\
\text { UCT IOW } \\
\text { kg/Yr }\end{array}$ & $\begin{array}{l}\text { DRINK } \\
\text { MATER } \\
\text { CONTAN } \\
\text { FRACT. }\end{array}$ & $\begin{array}{l}\text { DIET } \\
\text { FRAC- } \\
\text { TION }\end{array}$ & $\begin{array}{c}\text { GRON } \\
\text { I IME } \\
\text { da }\end{array}$ & $\begin{array}{l}\text { - STOREO } \\
\text {-IRRIGAT } \\
\text { s RATE } \\
\text { - In/Yr }\end{array}$ & $\begin{array}{l}\text { FEED-: } \\
\text { TIOW-:- } \\
\text { TIME } \\
\text { mo/Yr }\end{array}$ & $\begin{array}{l}\text { YIELD } \\
\mathrm{kg} / \mathrm{m}^{3}\end{array}$ & $\begin{array}{l}\text { STCR- } \\
\text { AGE } \\
\text { da }\end{array}$ \\
\hline $\begin{array}{l}F \\
F \\
F\end{array}$ & $\begin{array}{l}\text { BEEF } \\
\text { POULTR } \\
\text { HILK } \\
\text { EC6 }\end{array}$ & $\begin{array}{l}0.0 \\
0.0 \\
0.0 \\
0.0\end{array}$ & $\begin{array}{l}0.00 \\
0.00 \\
0.00 \\
0.00\end{array}$ & $\begin{array}{l}0.00 \\
0.00 \\
0.00 \\
0.00\end{array}$ & $\begin{array}{l}0.00 \\
0.00 \\
0.00 \\
0.00\end{array}$ & $\begin{array}{l}0.0 \\
0.0 \\
0.0 \\
0.0\end{array}$ & $\begin{array}{l}0.0 \\
0.0 \\
0.0 \\
0.0\end{array}$ & $\begin{array}{l}0.00 \\
0.00 \\
0.00 \\
0.00\end{array}$ & $\begin{array}{l}0.00 \\
0.00 \\
0.00 \\
0.00\end{array}$ & $\begin{array}{l}0.0 \\
0.0 \\
0.0 \\
0.0\end{array}$ \\
\hline & AI & & & & $\begin{array}{l}0.00 \\
0.00\end{array}$ & $\begin{array}{l}0.0 \\
0.0\end{array}$ & $\begin{array}{l}0 \\
0\end{array}$ & & $\begin{array}{l}0.00 \\
0.00\end{array}$ & 0.0 \\
\hline
\end{tabular}


WHC-SD-TP-PDC-030 Rev. 3

\section{HEDOP REYIEH CHECXLIST \\ for \\ Radiological and Nonradiological Release Calculations}

Document Reviewed: "SAFETY CLASSIFICATION FOR THE K BASIN CASK."

Submitted by: C. H. HUANG

Date Submitted: June 1, 1995

Scope of Review: Entire Document

YES $N 0^{*} \quad N / A$

[X] [ ] [ ] 1. A detailed technical review and approval of the environmental transport and dose calculation portion of the analys is has been performed and documented.

$\Delta$ [ ] [ ] 2. Detailed technical review(s) and approval(s) of scenario and release determinations have been performed and documented.

4 [ ] [ ] 3. HEDOP-approved cade(s) were used.

[] [] 7 . Receptor locations were selected according to HEDOP recommendations.

D4 [ ] [ ] 5. All applicable environmental pathways and code options were included and are appropriate for the calculations.

b [ ] [ ] 6. Hanford site data were used.

[] [ ] [7 7. Model adjustments external to the computer program were justified and performed correctly.

D. [ ] [ ] 8. The analysis is consistent with HEDOP recommendations.

9. Supporting notes, calculations, comments, comment resolutions, or other information is attached. (Use the "Page 1 of $X$ " page numbering format and sign and date each added page.)

(4) [ ] 10. Approval is granted on behalf of the Hanford Environmental Dose Overview Panel.

- A11 "NO" responses must be explained and use of nonstandard methods justified.

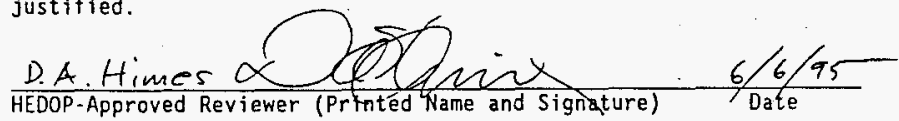

COMMENTS (add additional signed and dated pages if necessary): 
WHC-SD-TP-PDC-030 Rev. 3

CHECKLIST FOR PEER REVIEH

Document Reviewed: c. H. Huang, "SAFETY CLASSIFICATION FOR THE K BASIN CASK," June 1, 1995.

Scope of Review: Entire Document

Yes No NA

[ ] [ ] U * Previous reviews complete and cover analysis, up to scope of

$[x][$ [ ] Problem completely defined.

[X] [ ] Accident scenarios developed in a clear and logical manner.

[X [ ] [ N Necessary assumptions explicitly stated and supported.

$[X]$ [ [ ] Computer codes and data files documented.

Q] $\left[\begin{array}{lll} & 0\end{array}\right]$

Data used in calculations explicitly stated in document.

Data checked for consistency with original source information as applicable.

[ ] [ ] [] Mathematical derivations checked including dimensional consistency of results.

[] [ ] [ ] Models appropriate and used within range of validity or use

[x] [ ] [ ] outside range of established validity justified.

Hand calculations checked for errors. Spreadsheet results should be treated exactly the same as hand calculations.

[X] [ ] [ ] Software input correct and consistent with document reviewed. Software output consistent with input and with results reported in document reviewed.

K] [ ] $\partial_{i}$ "Limits/criteria/guidelines applied to analysis results are appropriate and referenced. Limits/criteria/guidelines checked against references.

[ ] [ ] [ $]$ Safety margins consistent with good engineering practices.

[ ] [ [ $[x]$ Conclusions consistent with analytical results and applicable limits.

K] [ ] [ ] Results and conclusions address all points required in the problem statement.

[ ] [ ] [x] Format consistent with appropriate NRC Regulatory Guide or other standards

[ ] [ $[x] \bullet$ Review calculations, comments, and/or notes are attached.

[x [ ] [ ] Document approved.

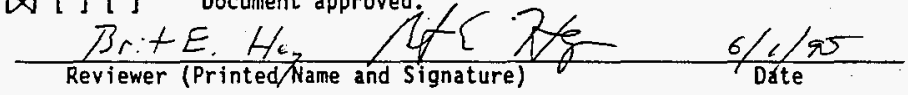


WHC-SD-TP-PDC-030 Rev. 3

This page intentionally left blank. 


\author{
WHC-SD-TP-PDC-030 Rev. 3 \\ APPENDIX B \\ ONSITE SARP TABLE OF CONTENTS
}

PART A: DESCRIPTION AND OPERATIONS

1.0 INTRODUCTION

1.1 GENERAL INFORMATION

1.2 SYSTEM DESCRIPTION

1.3 REVIEW AND UPDATE CYCLES

2.0 PACKAGING SYSTEM

2.1 CONFIGURATION AND DIMENSIONS

2.2 MATERIALS OF CONSTRUCTION

2.3 MECHANICAL PROPERTIES OF MATERIALS

2.4 DESIGN AND FABRICATION METHODS

2.5 WEIGHTS AND CENTER OF GRAVITY

2.6 CONTAINMENT BOUNDARY

2.7 CAVITY SIZE

2.8 HEAT DISSIPATION

2.9 SHIELDING

2.10 LIFTING DEVICES

2.11 TIEDOWN DEVICES

3.0 PACKAGE CONTENTS

3.1 GENERAL DESCRIPTION

3.2 CONTENT RESTRICTIONS

3.2.1 Content Matrix

3.2.2 Radioactive Materials

3.2.3 Nonradioactive Materials

4.0 TRANSPORT SYSTEM

4.1 TRANSPORTER

4.2 TIEDOWN SYSTEM

4.3 SPECIAL TRANSFER REQUIREMENTS

5.0 ACCEPTANCE OF PACKAGING FOR USE

5.1 NEW PACKAGING

5.1.1 Acceptance Requirements

5.1.2 Inspection and Testing

5.1.3 Documentation

5.2 PACKAGING FOR REUSE

5.2.1 Acceptance Requirements

5.2.2 Inspection and Testing

5.2.3 Documentation

6.0 OPERATING REQUIREMENTS

6.1 GENERAL REQUIREMENTS

6.2 LOADING PACKAGE

6.3 UNLOADING PACKAGE

6.4 EMPTY PACKAGING 


\subsection{QUALITY ASSURANCE REQUIREMENTS \\ 7.1 INTRODUCTION \\ 7.2 GENERAL REQUIREMENTS \\ 7.3 ORGANIZATION \\ 7.4 QUALITY ASSURANCE PLAN AND ACTIVITIES \\ 7.4.1 Design Control \\ 7.4.2 Procurement Control \\ 7.4.3 Fabrication Control \\ 7.4.4 Control and Inspection of testing \\ 7.4.5 Maintenance Checks and Controls \\ 7.4.6 Records and Document Control}

7.5 SARP CONTROL SYSTEM

8.0 MAINTENANCE

8.1 GENERAL REQUIREMENTS

8.2 INSPECTION AND VERIFICATION SCHEDULES

8.3 RECORDS AND DOCUMENTATION

9.0 APPENDIX

9.1 DRAWINGS

PART B: PACKAGE EVALUATION

1.0 INTRODUCTION

1.1 SAFETY EVALUATION METHODOLOGY

1.2 EVALUATION SUMMARY AND CONCLUSIONS

1.3 APPENDIX

2.0 CONTENTS EVALUATION

2.1 CHARACTERIZATION

2.2 RESTRICTIONS

2.3 SIZE AND WEIGHT

2.4 CONCLUSIONS

2.5 APPENDIX

3.0 RADIOLOGICAL RISK EVALUATION

3.1 INTRODUCTION

3.2 RISK ACCEPTANCE CRITERIA

3.3 DOSE CONSEQUENCE ANALYSIS

3.4 PACKAGE FAILURE THRESHOLD ANALYSIS

3.5 ACCIDENT FREQUENCY ASSESSMENT

3.5.1 Approach

3.5.2 Accident Sequence Event Tree Analysis

3.6 RISK EVALUATION AND CONCLUSIONS

3.7 APPENDIX 
WHC-SD-TP-PDC-030 Rev. 3

4.0 CONTAINMENT EVALUATION

4.1 INTRODUCTION

4.2 CONTAINMENT SOURCE SPECIFICATION

4.3 NORMAL TRANSFER CONDITIONS

4.3.1 Conditions to be Evaluated

4.3.2 Containment Acceptance Criteria

4.3.3 Containment Mode 1

4.3.4 Containment Calculations

4.4 ACCIDENT CONDITIONS

4.4.1 Conditions to be Evaluated

4.4.2. Containment Acceptance Criteria

4.4.3 Containment Model

4.4.4 Containment Calculations

4.5 CONTAINMENT EVALUATION AND CONCLUSIONS

4.6 APPENDIX

5.0 SHIELDING EVALUATION

5.1 INTRODUCTION

5.2 DIRECT RADIATION SOURCE SPECIFICATION

5.3 SUMMARY OF SHIELDING PROPERTIES OF MATERIALS

5.4 NORMAL TRANSFER CONDITIONS

5.4.1 Conditions to be Evaluated

5.4.2 Acceptance Criteria

5.4.3 Shielding Model

5.4.4 Shielding Calculations

5.5 ACCIDENT CONDITIONS

5.5.1 Conditions to be Evaluated

5.5.2 Acceptance Criteria

5.5.3 Shielding Model

5.5.4 Shielding Calculations

5.6 SHIELDING EVALUATION AND CONCLUSIONS

5.7 APPENDIX

6.0 CRITICALITY EVALUATION

6.1 INTRODUCTION

6.2 CRITICALITY SOURCE SPECIFICATION

6.3 SUMMARY OF CRITICALITY PROPERTIES OF MATERIALS

6.4 NORMAL TRANSFER CONDITIONS

6.4.1 Conditions To Be Evaluated

6.4.2 Acceptance Criteria

6.4.3 Criticality Model

6.4.4 Criticality Calculations

6.5 ACCIDENT CONDITIONS

6.5.1 Conditions To Be Evaluated

6.5.2 Acceptance Criteria

6.5.3 Criticality Model

6.5.4 Criticality Calculations

6.6 CRITICAL BENCHMARK EXPERIMENTS

6.6.1 Benchmark Experiments and Applicability

6.6.2 Details of Benchmark Calculations

6.6.3 Results of Benchmark Calculations

6.7 CRITICALITY EVALUATION AND CONCLUSIONS

6.8 APPENDIX 


\section{WHC-SD-TP-PDC-030 Rev. 3}

\subsection{STRUCTURAL EVALUATION}

7.1 INTRODUCTION

7.2 STRUCTURAL EVALUATION OF PACKAGE

7.2.1 Structural Design and Features

7.2.2 Mechanical Properties of Materials

7.2.3 Chemical and Galvanic Reactions

7.2.4 Size of Package and Cavity

7.2.5 Weights and Center of Gravity

7.2.6 Tamper-Indicating Feature

7.2.7 Positive Closure

7.2.8 Lifting and Tiedown Devices

7.2.9 Brittle Fracture

7.3 NORMAL TRANSFER CONDITIONS

7.3.1 Conditions to be Evaluated

7.3.2 Acceptance Criteria

7.3.3 Structural Model

7.3.4 Initial Conditions

7.3.4.1 Environmental Heat Loading

7.3.4.2 Maximum Thermal and Pressure Stresses

7.3.4.3 Structural Evaluations and Conclusions

7.4 ACCIDENT CONDITIONS

7.4.1 Conditions to be Evaluated

7.4.2 Acceptance Criteria

7.4.3 Structural Mode]

7.4.4 Initial Conditions

7.4.4.1 Environmental Heat Loading

7.4.4.2 Maximum Thermal and Pressure Stresses

7.5 APPENDIX

7.4.4.3 Structural Evaluation and Conclusions

8.0 THERMAL EVALUATION

8.1 INTRODUCTION

8.2 THERMAL SOURCE SPECIFICATION

8.3 SUMMARY OF THERMAL PROPERTIES OF MATERIALS

8.4 THERMAL EVALUATION FOR NORMAL TRANSFER CONDITIONS

8.4.1 Conditions to be Evaluated

8.4.2 Acceptance Criteria

8.4.3 Thermal Hodel

8.4.4 Thermal Analysis

8.4.4.1 Internal Temperatures

8.4.4.2 Maximum Surface Temperatures

8.5 THERMAL EVALUATION FOR ACCIDENT CONDITIONS

8.5.1 Conditions to be Evaluated

8.5.2 Acceptance Criteria

8.5.3 Package Conditions and Environment

8.5.4 Therma1 Mode1

8.5.5 Thermal Analysis

8.5.5.1 Internal Temperatures

8.5.5.2 Maximum Surface Temperatures

8.6 THERMAL EVALUATION AND CONCLUSIONS

8.7 APPENDIX 


$$
\text { WHC-SD-TP-PDC-030 Rev. } 3
$$

9.0 PRESSURE AND GAS GENERATION EVALUATION

9.1 GAS GENERATION

9.2 PACKAGE PRESSURE

9.3 APPENDIX

\subsection{PACKAGE TIEDOWN SYSTEM EVALUATION}

10.1 SYSTEM DESIGN

10.2 ATTACHMENTS AND RATINGS

10.3 APPENDIX (CALCULATIONS) 


\begin{tabular}{|c|c|c|c|c|c|}
\hline \multicolumn{6}{|c|}{ DISTRIBUTION SHEET } \\
\hline \multirow{2}{*}{$\begin{array}{l}\text { To } \\
\text { Distribution }\end{array}$} & \multirow{2}{*}{\multicolumn{3}{|c|}{$\begin{array}{l}\text { From } \\
\text { Packaging Engineering }\end{array}$}} & \multicolumn{2}{|c|}{ Page 1 of 1} \\
\hline & & & & \multicolumn{2}{|c|}{ Date $06 / 17 / 96$} \\
\hline \multirow{2}{*}{\multicolumn{4}{|c|}{$\begin{array}{l}\text { Project Title Work Order } \\
\text { Packaging Design Crite }\end{array}$}} & \multirow{2}{*}{\multicolumn{2}{|c|}{$\begin{array}{|ll|}\text { EDT No. } & \text { NA } \\
\text { ECN No. } & 630853 \\
\end{array}$}} \\
\hline & & & & & \\
\hline Name & MSIN & $\begin{array}{c}\text { Text } \\
\text { With All } \\
\text { Attach. }\end{array}$ & Text Only & $\begin{array}{l}\text { Attach./ } \\
\text { Appendix } \\
\text { Only }\end{array}$ & $\begin{array}{l}\text { EDT/ECN } \\
\text { Only }\end{array}$ \\
\hline $\begin{array}{l}\text { W. S. Edwards } \\
\text { J. G. Field } \\
\text { W. D. Gallo } \\
\text { J. R. Green } \\
\text { C. R. Hoover } \\
\text { A. T. Kee } \\
\text { D. W. McNally } \\
\text { W. J. Schlauder } \\
\text { S. S. Shiraga } \\
\text { R. J. Smith } \\
\text { Central Files }\end{array}$ & $\begin{array}{l}\text { G1-12 } \\
\text { GI-11 } \\
\text { R3-85 } \\
\text { GI-11 } \\
\text { G1-11 } \\
\text { R3-86 } \\
\text { G1-11 } \\
\text { S7-84 } \\
\text { G1-11 } \\
\text { G1-11 } \\
\text { A3-88 }\end{array}$ & $\begin{array}{l}x \\
x \\
x \\
x \\
x \\
x \\
x \\
x \\
x \\
x \\
x\end{array}$ & & & \\
\hline WHC-SD-TP-PDC-030 File & GI-11 & $x$ & & & \\
\hline
\end{tabular}

